Research article

\title{
A glimpse into the symplastic and apoplastic Cd uptake by Massai grass modulated by sulfur nutrition: Plants well-nourished with $S$ as a strategy for phytoextraction
}

\author{
Flávio Henrique Silveira Rabêlo ${ }^{\mathrm{a}, *}$, Luiz Tadeu Jordão ${ }^{\mathrm{b}}$, José Lavres ${ }^{\mathrm{a}}$ \\ ${ }^{\text {a }}$ University of São Paulo, Center for Nuclear Energy in Agriculture, Piracicaba, 13416-000, Brazil \\ b São Paulo State University, Faculty of Agricultural Sciences, Botucatu, 18610-307, Brazil
}

\section{A R T I C L E I N F O}

\section{Keywords:}

Cadmium

Kinetics

$\mathrm{K}_{\mathrm{m}}$

Panicum maximum

Sulfur

\begin{abstract}
A B S T R A C T
To date, there have been no studies demonstrating the influence of sulfur (S) on the cadmium (Cd) uptake kinetics, which limits the understanding of mechanisms involved in the uptake of this element. Therefore, this study was carried out in order to quantify the contribution of symplastic and apoplastic uptakes of Cd $(0.1$ and $0.5 \mathrm{mmol} \mathrm{L}^{-1}$ ) by Massai grass (Panicum maximum cv. Massai) grown under low and adequate S-supply $(0.1$ and $\left.1.9 \mathrm{mmol} \mathrm{L}^{-1}\right)$ by measuring $\mathrm{Cd}$ concentration in the nutrient solution $\left(\mathrm{V}_{\max }, \mathrm{K}_{\mathrm{m}}\right.$, and $\left.\mathrm{C}_{\min }\right)$ along the plant's exposure time $\left(108 \mathrm{~h}\right.$ ) and determining Cd concentration in root symplast and apoplast. The $\mathrm{V}_{\max }$ of Cd influx in Massai grass exposed to higher Cd and S concentrations was 38\% higher than that plants supplied with lower S concentration. The $\mathrm{K}_{\mathrm{m}}$ and $\mathrm{C}_{\mathrm{min}}$ of plants exposed to the highest Cd concentration was higher than that plants subjected to the lowest Cd concentration, although values were not affected by S supply. Symplastic influx of Cd in plants subjected to the lower Cd and S concentrations was $20 \%$ higher as compared to plants supplied with the higher concentration of S, whereas the apoplastic influx of Cd was higher when there was a higher supply S, regardless of $\mathrm{Cd}$ concentration in the solution. This result indicates that an adequate supply of $\mathrm{S}$ decreases the contribution of the symplastic Cd uptake and increases the contribution of the apoplastic Cd uptake when the toxicity caused by $\mathrm{Cd}$ is lower.
\end{abstract}

\section{Introduction}

The concentration of cadmium (Cd) in the environment has increased in the last decades due to the disposal of industrial and municipal waste in inappropriate areas and the application of phosphate fertilizers and sewage sludge, among other factors (Cataldo et al., 1983). This fact represents a major socio-economic problem, since Cd is toxic to plants, animals, and humans (Stritsis and Claassen, 2013). For this reason, several strategies to decrease the Cd concentration in the environment have been investigated, most notably phytoextraction (Sheoran et al., 2016). However, to this date, there are few known species of plants considered Cd hyperaccumulators, which fosters the study of other plants, as forage grasses (Zhao et al., 2002; Rabêlo and Borgo, 2016). These plants can offset the lower proportional accumulation of Cd with their higher biomass production, especially when grown with the adequate supply of sulfur (S) (Rabêlo and Borgo, 2016; Rabêlo et al., 2017a,b). Sulfur is a component of metabolites that act in the chelation and combat against the damage caused by Cd (eg), amino acids, reduced glutathione (GSH) and phytochelatins (PCs), and an adequate supply of this nutrient can increase the Cd extraction potential (Seth et al., 2012; Rabêlo et al., 2017a,b). However, so far, there have been no studies demonstrating the influence of S on Cd uptake kinetics, which limits the understanding of the mechanisms involved in the uptake of this element and the application of genetic breeding to optimize the phytoextraction.

Cadmium can enter cells from the root system through transporters of the ZIP (Zinc-regulated transporter/Iron-regulated transporter-like Protein) family, non-selective cation channels, or in the form of Cdchelates through YSL (Yellow-Stripe 1-Like) proteins (Lux et al., 2011). By this pathway, Cd can reach the Casparian strips via symplast,

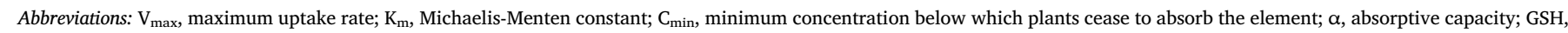

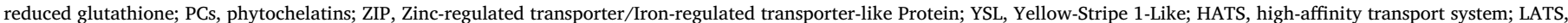

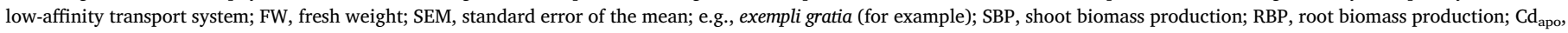
$\mathrm{Cd}$ concentration in apoplasto; $\mathrm{Cd}_{\text {sym }}$, Cd concentration in symplast; $\mathrm{Cd}_{\text {tot }}$, total Cd concentration; $\mathrm{S}_{\text {con }}$, S concentration; AFS, apparent free space; CEC, cation exchange capacity

* Corresponding author.

E-mail address: flaviohsr.agro@usp.br (F.H.S. Rabêlo).
} 
through the cytoplasm of cells from the root system connected by plasmodesmata (high-affinity transport system - HATS) (Redjala et al., 2009). However, uptake-kinetics studies have shown that the Cd influx, when at high concentrations, follows the Michaelis-Menten constant with a linear component (Costa and Morel, 1994; Harris and Taylor, 2004; Perriguey et al., 2008). This linear component has been attributed to the strong binding of $\mathrm{Cd}$ to the cell wall, but it may also represent the apoplastic Cd flow towards the xylem through transporters and/or channels (low-affinity transport system - LATS) (Lux et al., 2011). These uncertainties hamper a more precise characterization of the symplastic and apoplastic participations in the Cd uptake, especially in situations in which plants have been exposed to $\mathrm{Cd}$ for short periods (Sterckeman et al., 2011). In any event, the uptake kinetics of metals normally includes two stages: the first stage is rapid and occurs after the contact of the metal with the root system (passive system - apoplastic uptake), while the second is slower and depends on the metabolic activity (active system - symplastic uptake) (Sloof et al., 1995). However, the importance of each stage varies according to the species and the concentration of the heavy metal and of other ions (e.g., $\mathrm{SO}_{4}{ }^{2-}$ ) in solution (Redjala et al., 2009, 2010).

Although the sulfate $\left(\mathrm{SO}_{4}{ }^{2-}\right)$ does not compete with $\mathrm{Cd}$ for the same uptake sites, the adequate supply of S may increase the synthesis of thiol compounds (-SH) in the apoplast and alter the influx of $\mathrm{Cd}$ in this pathway, since Cd has a high affinity with thiol compounds (Nocito et al., 2002; Anjum et al., 2015). Thus, it is possible that the S supply results in a greater accumulation of the metal in this site, which is desirable, since the main site of $\mathrm{Cd}$ accumulation in tolerant plants is the root apoplast (Wójcik et al., 2005; Akhter et al., 2014). On the other hand, $\mathrm{S}$ is a component of the PCs [( $\gamma$-GluCys $)_{n}$-Gly, in which $n$ ranges from 2 to 11], which act in the sequestration of $\mathrm{Cd}$ from the cytosol to the vacuole (Cobbett and Goldsbrough, 2002). In this regard, the $S$ supply may increase the synthesis of PCs and consequently modify the Cd influx via symplast (Hart et al., 1998; Mendoza-Cózatl et al., 2008). It should be stressed that when exposed to Cd, some plants absorb more S (Nocito et al., 2002) and, consequently, the adequate supply of this nutrient may change the $\mathrm{Cd}$ uptake kinetics in relation to plants growing under low S supply because of the synthesis of thiol compounds (bonding and/or chelation of $\mathrm{Cd}$ ). In view of this scenario, the objective of this study was to identify the symplastic and apoplastic contributions in the Cd uptake by Massai grass (Panicum maximum cv. Massai) exposed to high Cd concentrations $\left(0.1\right.$ and $\left.0.5 \mathrm{mmol} \mathrm{L}^{-1}\right)$ under lower $\left(0.1 \mathrm{mmol} \mathrm{L}^{-1}\right)$ and higher $\left(1.9 \mathrm{mmol} \mathrm{L}^{-1}\right) \mathrm{S}$ supplies, since plants of this species have been evaluated in phytoextraction of $\mathrm{Cd}$ studies as a function of the S supply (Rabêlo et al., 2017a,b).

\section{Materials and methods}

\subsection{Plant material and treatments}

The study to evaluate the effect of S on the Cd uptake by the root system of Panicum maximum cv. Massai was carried out in a greenhouse (30.5 ${ }^{\circ} \mathrm{C}$ average temperature and $60.5 \%$ relative humidity of the air; Fig. S1 in the supplementary material), using plastic pots with $0.6 \mathrm{~L}$ capacity containing $0.5 \mathrm{~L}$ of a nutrient solution. Treatments were represented by combinations of two $\mathrm{S}$ concentrations $(0.1$ and $\left.1.9 \mathrm{mmol} \mathrm{L}^{-1}\right)$ and two Cd concentrations $\left(0.1\right.$ and $\left.0.5 \mathrm{mmol} \mathrm{L}^{-1}\right)$, in nutrient solutions modified from the solution of Epstein and Bloom (2005). The plastic pots used in the study were distributed as random blocks with four replications. The Cd concentrations tested in this study were high in relation to other studies of Cd uptake kinetics (Lombi et al., 2001; He et al., 2007), but relatively high and potentially toxic Cd concentrations are required to investigate the existence of Cd transport via LATS (Hart et al., 2002), mainly in plants that are possibly Cd hyperaccumulator, such as Massai grass.

\subsection{Development of the kinetics study}

Seeds were set to germinate in a tray containing expanded vermiculite, which was irrigated with deionized water in the first 14 days, and nutrient solution modified to meet the $S$ concentration of $0.1 \mathrm{mmol} \mathrm{L}^{-1}$ (diluted at $25 \%$ ionic strength) in the following nine days (days 15-23) to acclimatize the plants to the nutrient solution (Rabêlo et al., 2017a). After the 23 days of seeding, one seedling ( $\pm 10 \mathrm{~cm}$ height) was transferred to each pot containing undiluted nutrient solutions modified to meet the $S$ concentrations of 0.1 and $1.9 \mathrm{mmol} \mathrm{L}^{-1}$ (100\% ionic strength) for 19 days (days 24-42) to acclimatize the plants to S concentrations (Rabêlo et al., 2017a). Then, the solutions modified to meet the $\mathrm{S}$ and $\mathrm{Cd}$ concentrations were provided for seven days (days 43-49) to acclimatize the plants to concentrations of $S$ and Cd (Rabêlo et al., 2017a). On the next day (day 50), the nutrient solutions were modified to prevent the supply of $\mathrm{S}$ and $\mathrm{Cd}$ aiming to increase the absorptive capacity of these two elements, as has been demonstrated for other elements (Epstein and Hagen, 1952; Lee and Rudge, 1986). After $24 \mathrm{~h}$ of S and Cd deprivation, the solutions modified to meet the $\mathrm{S}$ and $\mathrm{Cd}$ concentrations were supplied again, for five days (days 51-55) to carry out the study of kinetics (Fig. S2A in the supplementary material). The nutrient solutions provided in each period of the kinetics study were kept constantly aerated (day and night) and renewed when the composition of the nutrient solution was modified (days 24, 43, 50, and 51) and when the same composition was used for more than seven consecutive days (15-23 and 24-42 periods). Solutions maintained for periods of more than seven days were renewed each seven days, and solutions maintained for periods of less than seven days (solutions supplied between the days 43-49, 50, and 51-55) were renewed only once, on days 43,50 , and 51 .

The composition and initial $\mathrm{pH}$ of the nutrient solutions used in the study is shown in Table 1, and the chemical speciation of the nutrient solution used between days 51-55 (period of collection of the nutrient solution for the calculation of kinetic parameters), calculated using Visual MINTEQ ${ }^{\circ}$ software v. 3.0 (Gustafsson, 2012), is described in Table 2. The initial $\mathrm{pH}$ values of the nutrient solutions used during the study ranged from 5.78 to 5.83 (Table 1). Xu et al. (2012) demonstrate that, in model phytoplankton species, modest variations in $\mathrm{pH}$ (within $0.4 \mathrm{pH}$ units of average seawater) have a negligible effect on the $\mathrm{Cd}$ uptake system.

After the period of deprivation of S and Cd in the nutrient solution (day 50), we began the supply of the modified solutions to meet the combinations of S and Cd concentrations (days 51-55), as well as the immediate sampling of the nutrient solution to determine the kinetic parameters according to the method proposed by Claassen and Barber (1974). Aliquots of $10 \mathrm{~mL}$ were collected every $15 \mathrm{~min}$ for the first $2 \mathrm{~h}$; every $30 \mathrm{~min}$ for the following $4 \mathrm{~h}$; every $60 \mathrm{~min}$ during the subsequent $6 \mathrm{~h}$; and, lastly, every $12 \mathrm{~h}$ until the end of the 108-h experiment. The volume of nutrient solutions in the pots was kept constant $(0.5 \mathrm{~L})$ during the collection period by adding deionized water (Claassen and Barber, 1974). At the end of last solution collection, plants were separated into shoot and root to determine the S and Cd concentrations (apoplast and symplast) and measure the plant biomass production.

\subsection{Determination of kinetic parameters}

The kinetic parameters (maximum uptake rate - $\mathrm{V}_{\text {max }}$; MichaelisMenten constant $-\mathrm{K}_{\mathrm{m}}$; minimum concentration below which plants cease to absorb the element - $\mathrm{C}_{\text {min }}$; and absorptive capacity - $\alpha$ ) were determined by following the method proposed by Claassen and Barber (1974), whose principle is the quantification of the reduction in the concentration of the element of interest of the solution over time as a function of its uptake by the plant root system. The $\mathrm{V}_{\max }$ and $\mathrm{K}_{\mathrm{m}}$ values were calculated by graphic-mathematical approach (Ruiz, 1985) using Cinetica Windows software v. 1.0 (Ruiz and Fernandes Filho, 1992). The $\mathrm{C}_{\min }$ value was estimated from the moment the Cd concentration in 
Table 1

Volumes and initial $\mathrm{pH}$ of stock solutions used in the preparation of the nutrient solutions provided in each period of the study of Cd uptake kinetics.

\begin{tabular}{|c|c|c|c|c|c|c|c|c|}
\hline \multirow{2}{*}{$\begin{array}{l}\mathrm{S}\left(\mathrm{mmol} \mathrm{L}^{-1}\right) \\
\mathrm{Cd}\left(\mathrm{mmol} \mathrm{L}^{-1}\right)\end{array}$} & 0.1 & 0.1 & 1.9 & 1.9 & 0.1 & 0.1 & 1.9 & 1.9 \\
\hline & 0.1 & 0.5 & 0.1 & 0.5 & 0.1 & 0.5 & 0.1 & 0.5 \\
\hline \multirow[t]{2}{*}{ Stock solution } & \multicolumn{8}{|c|}{ Volume used $\left(\mathrm{mL} \mathrm{L}^{-1}\right)$} \\
\hline & \multicolumn{4}{|c|}{ Days 0-14 } & \multicolumn{4}{|c|}{ Days $15-23$} \\
\hline $\mathrm{CdCl}_{2}\left(1 \mathrm{~mol} \mathrm{~L}^{-1}\right)$ & - & - & - & - & - & - & - & - \\
\hline $\mathrm{KH}_{2} \mathrm{PO}_{4}\left(1 \mathrm{~mol} \mathrm{~L}^{-1}\right)$ & - & - & - & - & 0.25 & 0.25 & 0.25 & 0.25 \\
\hline $\mathrm{NH}_{4} \mathrm{NO}_{3}\left(1 \mathrm{~mol} \mathrm{~L}^{-1}\right)$ & - & - & - & - & 1.13 & 1.13 & 1.13 & 1.13 \\
\hline $\mathrm{KNO}_{3}\left(1 \mathrm{~mol} \mathrm{~L}^{-1}\right)$ & - & - & - & - & 1.50 & 1.50 & 1.50 & 1.50 \\
\hline $\mathrm{KCl}\left(1 \mathrm{~mol} \mathrm{~L}^{-1}\right)$ & - & - & - & - & 0.25 & 0.25 & 0.25 & 0.25 \\
\hline $\mathrm{MgSO}_{4} \cdot 7 \mathrm{H}_{2} \mathrm{O}\left(1 \mathrm{~mol} \mathrm{~L}^{-1}\right)$ & - & - & - & - & 0.03 & 0.03 & 0.03 & 0.03 \\
\hline $\mathrm{MgCl}_{2} \cdot 6 \mathrm{H}_{2} \mathrm{O}\left(1 \mathrm{~mol} \mathrm{~L}^{-1}\right)$ & - & - & - & - & 0.48 & 0.48 & 0.03 & 0.03 \\
\hline $\mathrm{CaCl}_{2}\left(1 \mathrm{~mol} \mathrm{~L}^{-1}\right)$ & - & - & - & - & 1.25 & 1.25 & 1.25 & 1.25 \\
\hline Micronutrients - $\mathrm{Fe}^{\mathrm{a}}$ & - & - & - & - & 0.25 & 0.25 & 0.25 & 0.25 \\
\hline $\mathrm{Fe}(\mathrm{III})-\mathrm{EDTA}^{\mathrm{b}}$ & - & - & - & - & 0.25 & 0.25 & 0.25 & 0.25 \\
\hline $\mathrm{pH}\left(\mathrm{H}_{2} \mathrm{O}\right)$ & 5.89 & 5.89 & 5.89 & 5.89 & 5.80 & 5.80 & 5.80 & 5.80 \\
\hline Stock solution & \multicolumn{4}{|c|}{ Days $24-42$} & \multicolumn{4}{|c|}{ Days 43-49 } \\
\hline $\mathrm{CdCl}_{2}\left(1 \mathrm{~mol} \mathrm{~L}^{-1}\right)$ & - & - & - & - & 0.1 & 0.5 & 0.1 & 0.5 \\
\hline $\mathrm{KH}_{2} \mathrm{PO}_{4}\left(1 \mathrm{~mol} \mathrm{~L}^{-1}\right)$ & 1.0 & 1.0 & 1.0 & 1.0 & 1.0 & 1.0 & 1.0 & 1.0 \\
\hline $\mathrm{NH}_{4} \mathrm{NO}_{3}\left(1 \mathrm{~mol} \mathrm{~L}^{-1}\right)$ & 4.5 & 4.5 & 4.5 & 4.5 & 4.5 & 4.5 & 4.5 & 4.5 \\
\hline $\mathrm{KNO}_{3}\left(1 \mathrm{~mol} \mathrm{~L}^{-1}\right)$ & 6.0 & 6.0 & 6.0 & 6.0 & 6.0 & 6.0 & 6.0 & 6.0 \\
\hline $\mathrm{KCl}\left(1 \mathrm{~mol} \mathrm{~L}^{-1}\right)$ & 1.0 & 1.0 & 1.0 & 1.0 & 1.0 & 1.0 & 1.0 & 1.0 \\
\hline $\mathrm{MgSO}_{4} \cdot 7 \mathrm{H}_{2} \mathrm{O}\left(1 \mathrm{~mol} \mathrm{~L}^{-1}\right)$ & 0.1 & 0.1 & 1.9 & 1.9 & 0.1 & 0.1 & 1.9 & 1.9 \\
\hline $\mathrm{MgCl}_{2} \cdot 6 \mathrm{H}_{2} \mathrm{O}\left(1 \mathrm{~mol} \mathrm{~L}^{-1}\right)$ & 1.9 & 1.9 & 0.1 & 0.1 & 1.9 & 1.9 & 0.1 & 0.1 \\
\hline $\mathrm{CaCl}_{2}\left(1 \mathrm{~mol} \mathrm{~L}^{-1}\right)$ & 5.0 & 5.0 & 5.0 & 5.0 & 5.0 & 5.0 & 5.0 & 5.0 \\
\hline Micronutrients $-\mathrm{Fe}^{\mathrm{a}}$ & 1.0 & 1.0 & 1.0 & 1.0 & 1.0 & 1.0 & 1.0 & 1.0 \\
\hline $\mathrm{Fe}(\mathrm{III})-\mathrm{EDTA}^{\mathrm{b}}$ & 1.0 & 1.0 & 1.0 & 1.0 & 1.0 & 1.0 & 1.0 & 1.0 \\
\hline $\mathrm{pH}\left(\mathrm{H}_{2} \mathrm{O}\right)$ & 5.80 & 5.80 & 5.80 & 5.80 & 5.79 & 5.83 & 5.78 & 5.79 \\
\hline Stock solution & \multicolumn{4}{|c|}{ Day 50} & \multicolumn{4}{|c|}{ Days $51-55$} \\
\hline $\mathrm{CdCl}_{2}\left(1 \mathrm{~mol} \mathrm{~L}^{-1}\right)$ & - & - & - & - & 0.1 & 0.5 & 0.1 & 0.5 \\
\hline $\mathrm{KH}_{2} \mathrm{PO}_{4}\left(1 \mathrm{~mol} \mathrm{~L}^{-1}\right)$ & 1.0 & 1.0 & 1.0 & 1.0 & 1.0 & 1.0 & 1.0 & 1.0 \\
\hline $\mathrm{NH}_{4} \mathrm{NO}_{3}\left(1 \mathrm{~mol} \mathrm{~L}^{-1}\right)$ & 4.5 & 4.5 & 4.5 & 4.5 & 4.5 & 4.5 & 4.5 & 4.5 \\
\hline $\mathrm{KNO}_{3}\left(1 \mathrm{~mol} \mathrm{~L}^{-1}\right)$ & 6.0 & 6.0 & 6.0 & 6.0 & 6.0 & 6.0 & 6.0 & 6.0 \\
\hline $\mathrm{KCl}\left(1 \mathrm{~mol} \mathrm{~L}^{-1}\right)$ & 1.0 & 1.0 & 1.0 & 1.0 & 1.0 & 1.0 & 1.0 & 1.0 \\
\hline $\mathrm{MgSO}_{4} \cdot 7 \mathrm{H}_{2} \mathrm{O}\left(1 \mathrm{~mol} \mathrm{~L}^{-1}\right)$ & - & - & - & - & 0.1 & 0.1 & 1.9 & 1.9 \\
\hline $\mathrm{MgCl}_{2} \cdot 6 \mathrm{H}_{2} \mathrm{O}\left(1 \mathrm{~mol} \mathrm{~L}^{-1}\right)$ & 2.0 & 2.0 & 2.0 & 2.0 & 1.9 & 1.9 & 0.1 & 0.1 \\
\hline $\mathrm{CaCl}_{2}\left(1 \mathrm{~mol} \mathrm{~L}^{-1}\right)$ & 5.0 & 5.0 & 5.0 & 5.0 & 5.0 & 5.0 & 5.0 & 5.0 \\
\hline Micronutrients - $\mathrm{Fe}^{\mathrm{a}}$ & 1.0 & 1.0 & 1.0 & 1.0 & 1.0 & 1.0 & 1.0 & 1.0 \\
\hline Fe (III)-EDTA ${ }^{b}$ & 1.0 & 1.0 & 1.0 & 1.0 & 1.0 & 1.0 & 1.0 & 1.0 \\
\hline $\mathrm{pH}\left(\mathrm{H}_{2} \mathrm{O}\right)$ & 5.83 & 5.83 & 5.83 & 5.83 & 5.79 & 5.83 & 5.78 & 5.79 \\
\hline
\end{tabular}

a Composition of the micronutrient solution $\left(\mu \mathrm{mol} \mathrm{L}{ }^{-1}\right)$ : $\mathrm{KCl}=50 ; \mathrm{H}_{3} \mathrm{BO}_{3}=25$; $\mathrm{MnSO}_{4} \cdot \mathrm{H}_{2} \mathrm{O}=2 ; \mathrm{ZnSO}_{4} \cdot 7 \mathrm{H}_{2} \mathrm{O}=2 ; \mathrm{CuSO}_{4} \cdot 5 \mathrm{H}_{2} \mathrm{O}=0.5 ; \mathrm{H}_{2} \mathrm{MoO}_{4}\left(85 \% \mathrm{MoO}_{3}\right)=0.5$.

${ }^{\mathrm{b}} \mathrm{Fe}(\mathrm{III})-\mathrm{EDTA}=100 \mu \mathrm{mol} \mathrm{L}{ }^{-1}$.

the exhaust solution remained constant, and $\alpha$ was obtained by the $\mathrm{V}_{\mathrm{max}} / \mathrm{K}_{\mathrm{m}}$ ratio (Keleti and Welch, 1984). The Cd depletion curves (decrease in the Cd concentration in the nutrient solution over time) were adjusted by using the graphic-mathematical model proposed by Ruiz (1985). The symplastic Cd influx was calculated by the equation of Claassen and Barber (1974):

$\mathrm{I}_{\mathrm{s}}=\frac{\mathrm{V}_{\max } \times[\mathrm{Cd}]}{\mathrm{K}_{\mathrm{m}}+[\mathrm{Cd}]}$

where $\mathrm{I}_{\mathrm{s}}$ is the symplastic Cd influx ( $\mathrm{mmol} \mathrm{g}^{-1} \mathrm{FW} \mathrm{h}^{-1}$ ), $\mathrm{V}_{\max }$ is the maximum $\mathrm{Cd}$ uptake rate $\left(\mathrm{mmol} \mathrm{g}^{-1} \mathrm{FW} \mathrm{h}^{-1}\right), \mathrm{K}_{\mathrm{m}}$ is the MichaelisMenten constant $\left(\mathrm{mmol} \mathrm{L}^{-1}\right)$, and [Cd] represents the Cd concentration in the nutrient solution. Afterwards, the apoplastic Cd influx was obtained by the equation described by Lombi et al. (2001):

$\mathrm{I}_{\mathrm{a}}=\frac{\mathrm{V}_{\max } \times[\mathrm{Cd}]}{\mathrm{K}_{\mathrm{m}}+[\mathrm{Cd}]}+a[\mathrm{Cd}]$

where $\mathrm{I}_{\mathrm{a}}$ is the apoplastic influx of $\mathrm{Cd}\left(\mathrm{mmol} \mathrm{g}^{-1} \mathrm{FW} \mathrm{h}^{-1}\right)$ and $a$ is the decline of the linear component. It is noteworthy that this equation has been used to calculate the symplastic influx of Cd (Redjala et al., 2009), but there is evidence that the linear component of this equation can represent the Cd influx via apoplast (Lux et al., 2011). After the calculations, the curves of the Cd symplastic and apoplastic influxes were adjusted using SigmaPlot ${ }^{\circledR}$ software v. 13.0 (Systat Soft. Inc., 2015).

\subsection{Determination of $C d$ concentrations in apoplast and symplast and $S$}

The concentrations of $\mathrm{Cd}$ (apoplast and symplast) and S were determined only in the root system of the plants. The Cd concentration in the apoplast and symplast was determined according to the methods described by Lavres Junior et al. (2008) and Mori et al. (2009), with modifications. The root system of the Massai grass was divided into two longitudinal sections with equivalent masses; one of the sections was immersed in a container with $150 \mathrm{~mL}$ of the "desorption" solution (2 $\mathrm{mmol} \mathrm{L}^{-1} \mathrm{CuCl}_{2}, 0.5 \mathrm{mmol} \mathrm{L}^{-1} \mathrm{CaCl}_{2}$, and $100 \mathrm{mmol} \mathrm{L}^{-1} \mathrm{HCl}$ ) at $5{ }^{\circ} \mathrm{C}$ for $30 \mathrm{~min}$ (Fig. S2B in the supplementary material). $\mathrm{CaCl}_{2}$ $0.5 \mathrm{mmol} \mathrm{L}^{-1}$ was used to the maintain cell wall integrity during the desorption of $\mathrm{Cd}$ and $\mathrm{CuCl}_{2} 2 \mathrm{mmol} \mathrm{L}^{-1}$ for the release of the $\mathrm{Cd}\left(\mathrm{Cd}^{2+}\right)$ connected to the root apoplast exchange sites (adapted from Wang, 2003). After the desorption process, the sectioned part of the root system was washed in deionized water and dried in a forced-air oven at $60{ }^{\circ} \mathrm{C}$ for $72 \mathrm{~h}$, and so was the sectioned part that was not immersed in desorption solution. Subsequently, the plant material was ground (Wiley mill) and subjected to nitric-perchloric digestion, as described by Malavolta et al. (1997). The concentrations of S and Cd in the extract obtained after digestion were quantified by optic emission spectrophotometry with inductively coupled plasma (ICP-OES, Model iCAP 7000 SERIES, Thermo Scientific, Waltham, Massachusetts, USA). Later, the $\mathrm{Cd}$ concentration in apoplast was calculated as the total $\mathrm{Cd}$ concentration (part sectioned from the root system not immersed in desorption solution) minus the $\mathrm{Cd}$ concentration in symplast (part sectioned from the root system immersed in desorption solution).

\subsection{Determination of biomass production}

The biomass production of shoots and root system was obtained after the plant material was dried in a forced-air oven at $60{ }^{\circ} \mathrm{C}$ for $72 \mathrm{~h}$. Later, with the biomass production values, the root/shoot ratio was calculated.

\subsection{Statistical analysis}

The data were subjected to analysis of variance (F test) and means were compared by Tukey's test $(p<0.05)$ using the Statistical Analysis System v. 9.2 (SAS Institute, 2008). Results were expressed as means \pm standard error of the mean (SEM). Later, Pearson's correlation studies were performed among the analyzed variables (SAS Institute, 2008).

\section{Results}

\subsection{Biomass production and root/shoot ratio}

The highest biomass productions (shoot and root) of Massai grass occurred under lower availability of $\mathrm{Cd}\left(0.1 \mathrm{mmol} \mathrm{L}^{-1}\right)$ and higher Ssupply (1.9 mmol L $\mathrm{m}^{-1}$ ) in nutrient solution (Table 3 ). The biomass production of the shoot and root system of plants supplied with the highest S concentration was 73 and $130 \%$ higher compared with the biomass production of plants grown with the lower concentration of $S$, under reduced exposure to $\mathrm{Cd}\left(0.1 \mathrm{mmol} \mathrm{L}^{-1}\right)$. There was no significant effect $(p>0.05)$ of S supply on the biomass production of plants exposed to the higher $\mathrm{Cd}$ concentration in the solution. The biomass production of shoots of plants grown with the higher Cd availability was 40 and $74 \%$ lower than that of plants exposed to the lower $\mathrm{Cd}$ concentration when they were grown receiving $S$ supplies of 0.1 and 
Table 2

Chemical speciation of the nutrient solution ( $\mathrm{pH}$ 5.5) by Visual MINTEQ ${ }^{\circ}$ software.

\begin{tabular}{|c|c|c|c|c|c|c|c|}
\hline \multicolumn{4}{|c|}{$0.1 \mathrm{mmol} \mathrm{L}^{-1} \mathrm{~S}+0.1 \mathrm{mmol} \mathrm{L}^{-1} \mathrm{Cd}$} & \multicolumn{4}{|c|}{$0.1 \mathrm{mmol} \mathrm{L}^{-1} \mathrm{~S}+0.5 \mathrm{mmol} \mathrm{L}^{-1} \mathrm{Cd}$} \\
\hline S - Species & $(\%)$ & Cd - Species & $(\%)$ & S - Species & (\%) & Cd - Species & $(\%)$ \\
\hline $\mathrm{SO}_{4}^{-2}$ & $66.55^{\mathrm{b}}$ & $\mathrm{Cd}^{+2}$ & $58.77^{\mathrm{c}}$ & $\mathrm{SO}_{4}{ }^{-2}$ & 69.87 & $\mathrm{Cd}^{+2}$ & 52.88 \\
\hline $\mathrm{HSO}_{4}{ }^{-}$ & 5.04 & $\mathrm{CdCl}^{+}$ & 38.45 & $\mathrm{HSO}_{4}{ }^{-}$ & 0.01 & $\mathrm{CdCl}^{+}$ & 36.16 \\
\hline $\mathrm{CdSO}_{4}(\mathrm{aq})^{\mathrm{a}}$ & 0.23 & $\mathrm{CdCl}_{2}$ (aq) & 1.54 & $\mathrm{CdSO}_{4}(\mathrm{aq})$ & 1.07 & $\mathrm{CdCl}_{2}$ (aq) & 1.51 \\
\hline $\mathrm{MgSO}_{4}$ (aq) & 6.26 & $\mathrm{CdSO}_{4}(\mathrm{aq})$ & 0.23 & $\mathrm{MgSO}_{4}(\mathrm{aq})$ & 6.42 & $\mathrm{CdSO}_{4}(\mathrm{aq})$ & 0.21 \\
\hline $\mathrm{CaSO}_{4}(\mathrm{aq})$ & 18.54 & $\mathrm{CdNO}_{3}{ }^{+}$ & 0.96 & $\mathrm{CaSO}_{4}(\mathrm{aq})$ & 19.09 & $\mathrm{CdNH}_{3}{ }^{+2}$ & 0.01 \\
\hline $\mathrm{KSO}_{4}^{-}$ & 1.81 & $\mathrm{CdHPO}_{4}(\mathrm{aq})$ & 0.02 & $\mathrm{KSO}_{4}{ }^{-}$ & 1.90 & $\mathrm{CdNO}_{3}{ }^{+}$ & 0.86 \\
\hline $\mathrm{NH}_{4} \mathrm{SO}_{4}{ }^{-}$ & 1.56 & $\mathrm{CdEDTA}^{-2}$ & 0.01 & $\mathrm{NH}_{4} \mathrm{SO}_{4}^{-}$ & 1.63 & $\mathrm{CdHPO}_{4}(\mathrm{aq})$ & 7.96 \\
\hline- & - & CdHEDTA $^{-}$ & 0.02 & - & - & CdEDTA $^{-2}$ & 0.40 \\
\hline \multicolumn{4}{|c|}{$1.9 \mathrm{mmol} \mathrm{L}^{-1} \mathrm{~S}+0.1 \mathrm{mmol} \mathrm{L}^{-1} \mathrm{Cd}$} & \multicolumn{4}{|c|}{$1.9 \mathrm{mmol} \mathrm{L}^{-1} \mathrm{~S}+0.5 \mathrm{mmol} \mathrm{L}^{-1} \mathrm{Cd}$} \\
\hline S - Species & $(\%)$ & Cd - Species & $(\%)$ & S - Species & $(\%)$ & Cd - Species & $(\%)$ \\
\hline $\mathrm{SO}_{4}{ }^{-2}$ & 71.91 & $\mathrm{Cd}^{+2}$ & 51.63 & $\mathrm{SO}_{4}{ }^{-2}$ & 71.50 & $\mathrm{Cd}^{+2}$ & 51.18 \\
\hline $\mathrm{HSO}_{4}{ }^{-}$ & 0.01 & $\mathrm{CdCl}^{+}$ & 33.51 & $\mathrm{HSO}_{4}{ }^{-}$ & 0.01 & $\mathrm{CdCl}^{+}$ & 34.56 \\
\hline $\mathrm{CdSO}_{4}(\mathrm{aq})$ & 0.21 & $\mathrm{CdCl}_{2}$ (aq) & 1.33 & $\mathrm{CdSO}_{4}(\mathrm{aq})$ & 1.03 & $\mathrm{CdCl}_{2}$ (aq) & 1.44 \\
\hline $\mathrm{MgSO}_{4}(\mathrm{aq})$ & 6.16 & $\mathrm{CdSO}_{4}(\mathrm{aq})$ & 4.00 & $\mathrm{Cd}\left(\mathrm{SO}_{4}\right)_{2}{ }^{-2}$ & 0.04 & $\mathrm{CdSO}_{4}(\mathrm{aq})$ & 3.90 \\
\hline $\mathrm{CaSO}_{4}(\mathrm{aq})$ & 18.11 & $\mathrm{Cd}\left(\mathrm{SO}_{4}\right)_{2}{ }^{-2}$ & 0.07 & $\mathrm{MgSO}_{4}$ (aq) & 6.05 & $\mathrm{Cd}\left(\mathrm{SO}_{4}\right)_{2}{ }^{-2}$ & 0.07 \\
\hline $\mathrm{KSO}_{4}{ }^{-}$ & 1.93 & $\mathrm{CdNH}_{3}{ }^{+2}$ & 0.01 & $\mathrm{CaSO}_{4}(\mathrm{aq})$ & 17.82 & $\mathrm{CdNH}_{3}{ }^{+2}$ & 0.01 \\
\hline $\mathrm{NH}_{4} \mathrm{SO}_{4}{ }^{-}$ & 1.66 & $\mathrm{CdNO}_{3}{ }^{+}$ & 0.84 & $\mathrm{KSO}_{4}{ }^{-}$ & 1.91 & $\mathrm{CdNO}_{3}{ }^{+}$ & 0.82 \\
\hline- & - & $\mathrm{CdHPO}_{4}(\mathrm{aq})$ & 7.80 & $\mathrm{NH}_{4} \mathrm{SO}_{4}^{-}$ & 1.64 & $\mathrm{CdHPO}_{4}(\mathrm{aq})$ & 7.62 \\
\hline- & - & $\mathrm{CdEDTA}^{-2}$ & 0.79 & - & - & $\mathrm{CdEDTA}^{-2}$ & 0.40 \\
\hline
\end{tabular}

a aq - aqua complex.

${ }^{\text {b }}$ Variation $<5 \%$ in $\mathrm{SO}_{4}{ }^{-2}$ availability ( $\mathrm{pH} 3.5$ to 5.5 ).

${ }^{c}$ Variation $<10 \%$ in $\mathrm{Cd}^{+2}$ availability (pH 3.5 to 5.5 ).

Table 3

Biomass production (shoots and roots) and root/shoot ratio of Massai grass supplied with $\mathrm{S}$ and exposed to $\mathrm{Cd}$.

\begin{tabular}{lllll}
\hline $\begin{array}{l}\mathrm{Cd} \\
(\mathrm{mmol} \\
\left.\mathrm{L}^{-1}\right)\end{array}$ & $\begin{array}{l}\mathrm{S}(\mathrm{mmol} \\
\left.\mathrm{L}^{-1}\right)\end{array}$ & $\begin{array}{l}\text { Shoot biomass } \\
\text { (g/plant) }\end{array}$ & $\begin{array}{l}\text { Root biomass }(\mathrm{g} / \\
\text { plant) }\end{array}$ & Root/shoot ratio \\
\hline 0.1 & 0.1 & $0.70 \pm 0.055 \mathrm{~b}$ & $0.10 \pm 0.010 \mathrm{~b}$ & $0.14 \pm 0.013 \mathrm{a}$ \\
& 1.9 & $1.21 \pm 0.082 \mathrm{a}$ & $0.23 \pm 0.015 \mathrm{a}$ & $0.19 \pm 0.014 \mathrm{a}$ \\
\hline 0.5 & 0.1 & $0.42 \pm 0.035 \mathrm{c}$ & $0.03 \pm 0.003 \mathrm{c}$ & $0.07 \pm 0.006 \mathrm{~b}$ \\
& 1.9 & $0.32 \pm 0.031 \mathrm{c}$ & $0.01 \pm 0.003 \mathrm{c}$ & $0.05 \pm 0.011 \mathrm{~b}$
\end{tabular}

Means \pm SEM followed by different letters in the column differ by Tukey's test $(p<0.05)$.

$1.9 \mathrm{mmol} \mathrm{L}^{-1}$, while in the root system there was a decrease of 70 and $96 \%$, respectively. There was a significant effect $(p<0.05)$ only of Cd concentrations on the root system/shoot ratio; in plants subjected to the lower concentration of $\mathrm{Cd}$, this ratio was 100 and $280 \%$ higher than in plants exposed to the higher concentration $\mathrm{Cd}$, with the lower and higher supplies of $\mathrm{S}$, respectively.

\subsection{Depletion of $\mathrm{Cd}$ in the nutrient solution}

The Cd depletion in the nutrient solution fit the potential model better, irrespective of the concentration of $\mathrm{Cd}$ and S (Fig. 1). In all combinations of Cd and S concentrations evaluated, the Cd concentration in the solution was reduced practically to half after $12 \mathrm{~h}$ of exposure of the Massai grass to the treatments. The Cd concentration in the nutrient solution of the plants exposed to lower $\mathrm{Cd}$ and $\mathrm{S}$ concentrations was $0.051 \mathrm{mmol} \mathrm{L}^{-1}$ (Fig. 1A), while in the nutrient solution of the plants subjected to the lower concentration of $\mathrm{Cd}$ and highest concentration of $\mathrm{S}$, the $\mathrm{Cd}$ concentration was $0.038 \mathrm{mmol} \mathrm{L}^{-1}$ (Fig. 1B). When the Massai grass was exposed to the higher Cd concentration, the $\mathrm{Cd}$ concentration in the nutrient solution after $12 \mathrm{~h}$ was $0.199 \mathrm{mmol} \mathrm{L}^{-1}$ (Fig. 1C) and $0.196 \mathrm{mmol} \mathrm{L}^{-1}$ (Fig. 1D), when $\mathrm{S}$ was supplied in the amounts of 0.1 and $1.9 \mathrm{mmol} \mathrm{L}^{-1}$, respectively. The Cd concentration in the nutrient solution remained constant after $72 \mathrm{~h}$ of exposure of plants to the combinations of $\mathrm{Cd}$ and $\mathrm{S}$ concentrations, and the $\mathrm{C}_{\min }$ value was estimated at that moment.

\subsection{Kinetic parameters}

The kinetic parameters evaluated here $\left(\mathrm{V}_{\max }, \mathrm{K}_{\mathrm{m}}, \mathrm{C}_{\min }\right.$, and $\left.\alpha\right)$ were changed significantly $(p<0.05)$ by the combination of $\mathrm{Cd}$ and $\mathrm{S}$ concentrations (Table 4). The highest $V_{\max }$ was observed in the Massai grass exposed to the higher $\mathrm{Cd}$ concentration and supplied with the $\mathrm{S}$ concentration of $1.9 \mathrm{mmol} \mathrm{L}^{-1}$. This value was $38 \%$ higher than the $\mathrm{V}_{\text {max }}$ of the plants exposed to the higher concentration of Cd and grown under the lower S supply. Plants exposed to the higher Cd concentration displayed a 27 and 45 times higher $\mathrm{V}_{\max }$ than those exposed to the $\mathrm{Cd}$ concentration of $0.1 \mathrm{mmol} \mathrm{L}^{-1}$ when $\mathrm{S}$ was supplied at 0.1 and $1.9 \mathrm{mmol} \mathrm{L}^{-1}$. The $\mathrm{K}_{\mathrm{m}}$ values of the Massai grass cultivated with the higher Cd concentration were 493 and 500\% higher in relation to the $\mathrm{K}_{\mathrm{m}}$ of the plants exposed to the lower Cd concentration when the $\mathrm{S}$ supply was 0.1 and $1.9 \mathrm{mmol} \mathrm{L}^{-1}$, respectively. Similar results were found for $\mathrm{C}_{\min }$, which was 508 and $435 \%$ higher in the Massai grass exposed to the higher $\mathrm{Cd}$ concentration with the lower and higher supplies of $\mathrm{S}$, as compared with plants exposed to the Cd concentration of $0.1 \mathrm{mmol} \mathrm{L}^{-1}$. Thus, as occurred for $\mathrm{V}_{\max }$, the highest $\alpha$ value was found in plants exposed to the Cd concentration of $0.5 \mathrm{mmol} \mathrm{L}^{-1}$ and to the $\mathrm{S}$ concentration of $1.9 \mathrm{mmol} \mathrm{L}^{-1}$, which showed a $30 \%$ greater $\mathrm{Cd}$ absorptive capacity $(\alpha)$ than plants grown under the higher Cd concentration and lower $\mathrm{S}$ concentration. The absorptive capacity of plants exposed to the higher concentration of $\mathrm{Cd}$ was 376 and $668 \%$ greater than that of plants exposed to $0.1 \mathrm{mmol} \mathrm{L}^{-1} \mathrm{Cd}$ with the lower and higher $\mathrm{S}$ supplies in the nutrient solution, respectively.

\subsection{Symplastic and apoplastic Cd influx}

The symplastic influx of Cd from the Massai grass grown under the lower S concentration was $20 \%$ higher than that of plants supplied with the higher $\mathrm{S}$ concentration when they were exposed to $0.1 \mathrm{mmol} \mathrm{L}^{-1} \mathrm{Cd}$ (Fig. 2A). However, when the Massai grass was exposed to the higher Cd concentration, the apoplastic influx of the plants supplied with the 

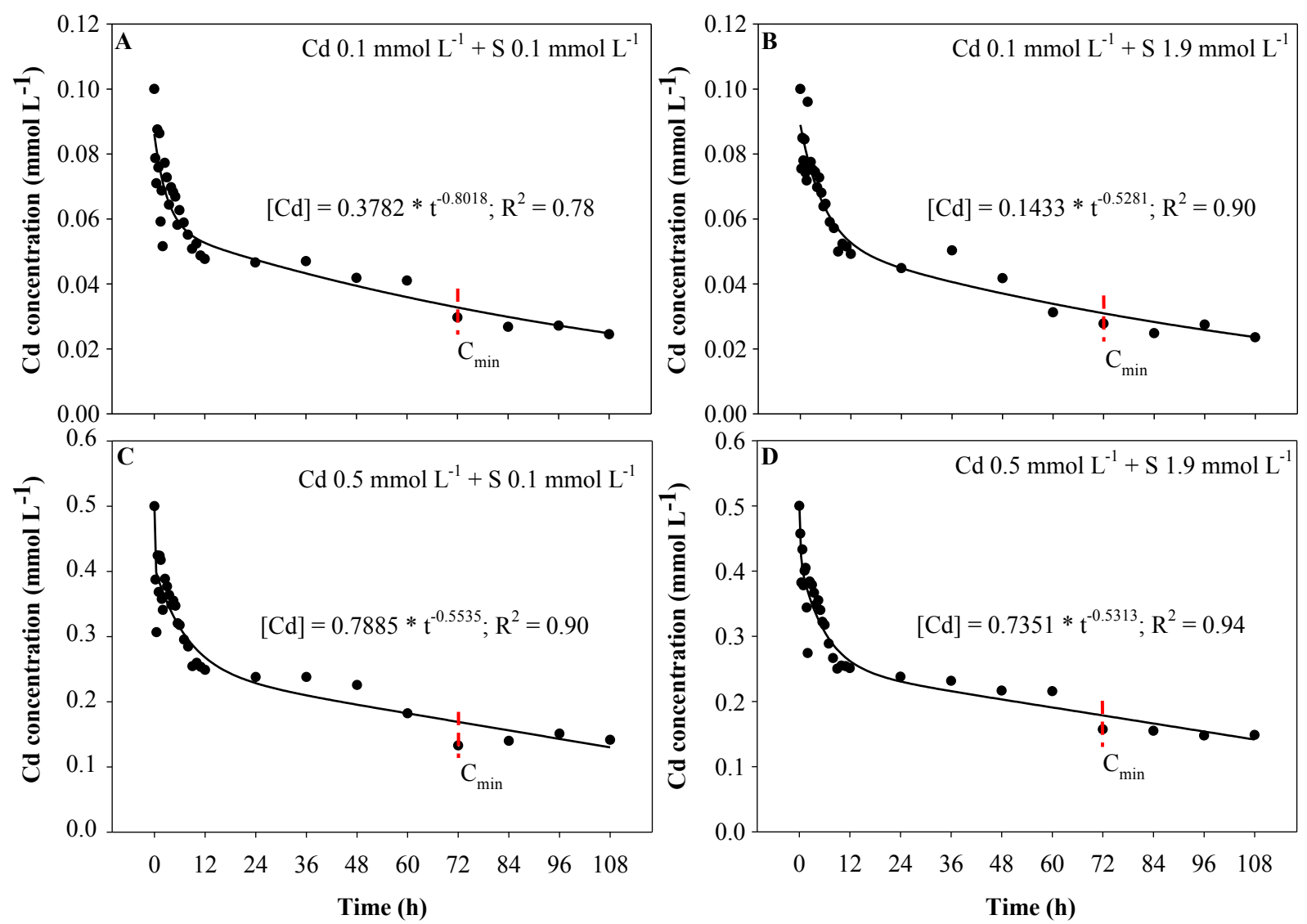

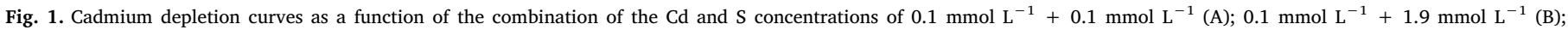
$0.5 \mathrm{mmol} \mathrm{L}{ }^{-1}+0.1 \mathrm{mmol} \mathrm{L}-1(\mathrm{C})$; and $0.5 \mathrm{mmol} \mathrm{L}^{-1}+1.9 \mathrm{mmol} \mathrm{L}^{-1}(\mathrm{D})$, and of the time of collection of nutrient solution aliquots.

lower S concentration was $26 \%$ lower than that of plants supplied with the higher S concentration (Fig. 2B). The symplastic influx of Cd from the Massai grass under the higher Cd concentration was 26 and 44 times greater than that of plants exposed to the lower Cd concentration when $S$ was available at 0.1 and $1.9 \mathrm{mmol} \mathrm{L}^{-1}$ in the nutrient solution (Fig. 2A and B). The highest apoplastic influxes of Cd from the Massai grass exposed to the $\mathrm{Cd}$ concentrations of 0.1 (Fig. 2C) and $0.5 \mathrm{mmol} \mathrm{L}^{-1}$ (Fig. 2D) were observed when plants were supplied with the $\mathrm{S}$ concentration of $1.9 \mathrm{mmol} \mathrm{L}^{-1}$. The higher supply of this nutrient resulted in a 24 and $68 \%$ higher apoplastic Cd influx in relation to the plants under lower $\mathrm{S}$, when the Massai grass was exposed to the $\mathrm{Cd}$ concentrations of 0.1 and $0.5 \mathrm{mmol} \mathrm{L}^{-1}$, respectively. The Cd influx via apoplast of the plants exposed to $0.5 \mathrm{mmol} \mathrm{L}^{-1} \mathrm{Cd}$ was 32 and 43 times higher than the apoplastic influx of the Massai grass exposed to the lower $\mathrm{Cd}$ concentration when $\mathrm{S}$ was supplied in the amounts of 0.1 and $1.9 \mathrm{mmol} \mathrm{L}^{-1}$, respectively (Fig. $2 \mathrm{C}$ and D).

\subsection{Concentrations of $C d$ (apoplast and symplast) and $S$}

The Cd concentrations significantly changed $(p<0.05)$ the $\mathrm{Cd}$ concentration in apoplast, symplast, and total $\mathrm{Cd}$ concentration, whereas the $\mathrm{S}$ concentrations changed the concentration of $\mathrm{S}$. The $\mathrm{Cd}$ concentration in apoplast of plants exposed to the higher Cd concentration was 110 and $126 \%$ higher than that of plants exposed to the lower Cd concentration when $\mathrm{S}$ was supplied at 0.1 and $1.9 \mathrm{mmol} \mathrm{L}^{-1}$, respectively, whereas the Cd concentration in symplast was 89 and $102 \%$ higher for the same comparison. The Cd concentration in apoplast was $46,60,62$, and $79 \%$ higher than the Cd concentration in symplast when the plants were grown with the $\mathrm{Cd}\left(\mathrm{mmol} \mathrm{L}^{-1}\right)$ and $\mathrm{S}$

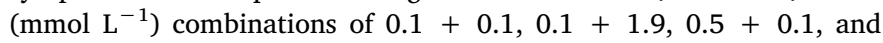
$0.5+1.9$, respectively. By contrast, the total concentration of $\mathrm{Cd}$ of the plants exposed to the higher Cd concentration was 101 and $116 \%$ greater than that of plants exposed to the $\mathrm{Cd}$ concentration of $0.1 \mathrm{mmol} \mathrm{L}^{-1}$ in the lower and higher supply of $S$ in the nutrient solution. The Massai grass supplied with the higher S supply showed a 94 and $58 \%$ higher concentration of $S$ in the root system in relation to the

Table 4

Kinetic parameters $\mathrm{V}_{\max }, \mathrm{K}_{\mathrm{m}}, \mathrm{C}_{\min }$ and absorptive capacity $\left(\alpha=\mathrm{V}_{\max } / \mathrm{K}_{\mathrm{m}}\right.$ ) estimated from the uptake of Cd by Massai grass supplied with $\mathrm{S}$ and exposed to Cd.

\begin{tabular}{|c|c|c|c|c|c|}
\hline \multirow[t]{2}{*}{$\mathrm{Cd}\left(\mathrm{mmol} \mathrm{L}^{-1}\right)$} & \multirow[t]{2}{*}{$\mathrm{S}\left(\mathrm{mmol} \mathrm{L}{ }^{-1}\right)$} & $\mathrm{V}_{\max }$ & $\mathrm{K}_{\mathrm{m}}$ & $\mathrm{C}_{\min }$ & $\alpha$ \\
\hline & & $\mu \mathrm{mol} \mathrm{g}{ }^{-1} \mathrm{FW} \mathrm{h}^{-1}$ & $\mu \mathrm{mol} \mathrm{L}-1$ & $\mu \mathrm{mol} \mathrm{L}-1$ & - \\
\hline \multirow[t]{2}{*}{0.1} & 0.1 & $0.0082 \pm 0.0003 c$ & $0.045 \pm 0.002 \mathrm{~b}$ & $0.012 \pm 0.001 \mathrm{~b}$ & $0.184 \pm 0.008 \mathrm{c}$ \\
\hline & 1.9 & $0.0069 \pm 0.0005 \mathrm{c}$ & $0.047 \pm 0.002 \mathrm{~b}$ & $0.014 \pm 0.001 \mathrm{~b}$ & $0.148 \pm 0.013 \mathrm{c}$ \\
\hline \multirow[t]{2}{*}{0.5} & 0.1 & $0.2319 \pm 0.0078 \mathrm{~b}$ & $0.267 \pm 0.016 \mathrm{a}$ & $0.073 \pm 0.001 \mathrm{a}$ & $0.876 \pm 0.056 \mathrm{~b}$ \\
\hline & 1.9 & $0.3212 \pm 0.0047 \mathrm{a}$ & $0.282 \pm 0.004 \mathrm{a}$ & $0.075 \pm 0.001 \mathrm{a}$ & $1.137 \pm 0.055 \mathrm{a}$ \\
\hline
\end{tabular}

Means \pm SEM followed by different letters in the column differ by Tukey's test $(p<0.05)$. 

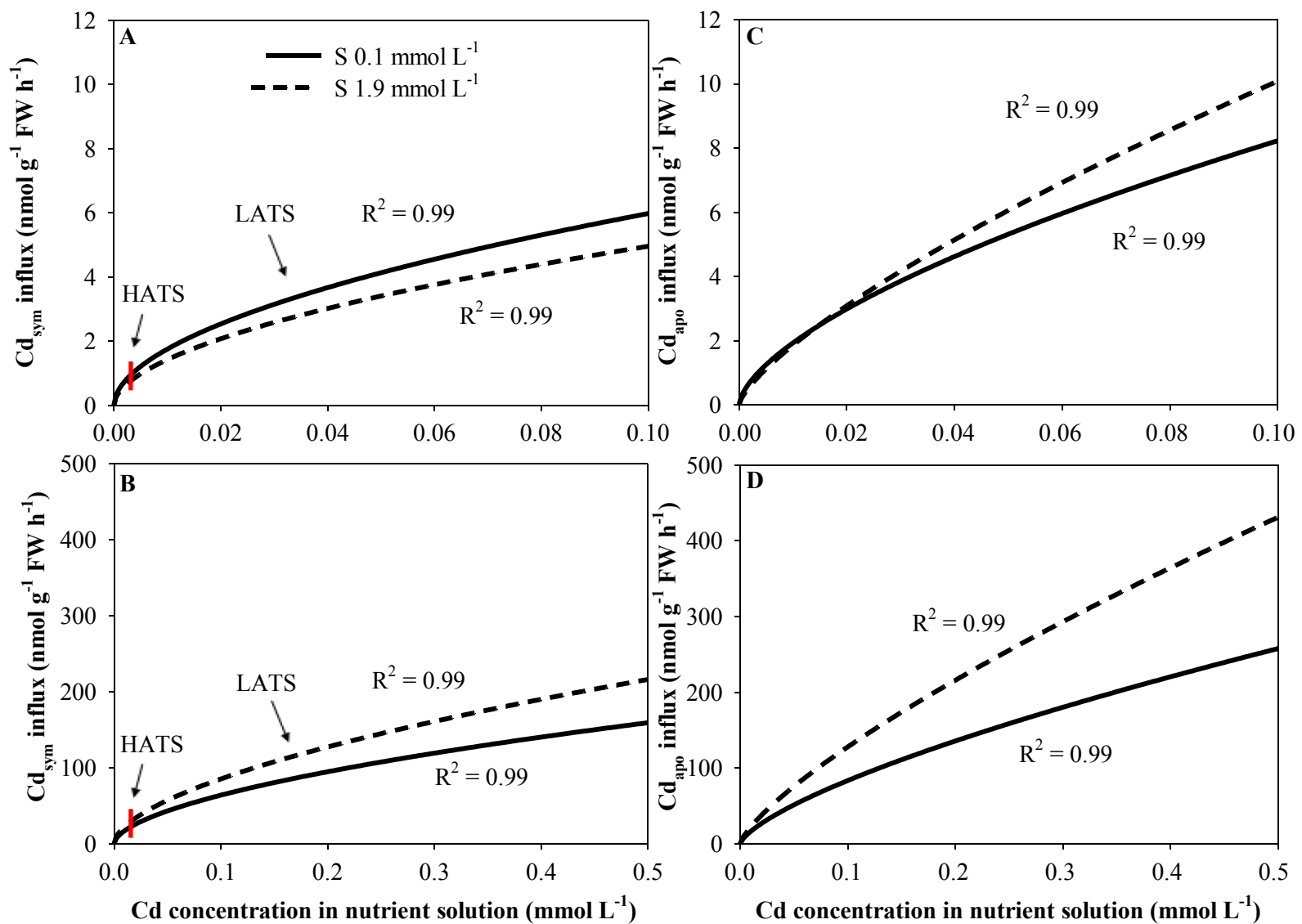

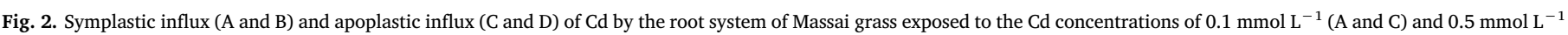
(B and D) and supplied with the $\mathrm{S}$ concentrations of 0.1 and $1.9 \mathrm{mmol} \mathrm{L}^{-1}$ in nutrient solution.

Table 5

Cadmium concentrations in apoplast, symplast, and apoplast + symplast (total), and S concentration in the roots of Massai grass supplied with S and exposed to Cd.

\begin{tabular}{|c|c|c|c|c|c|}
\hline \multirow[t]{2}{*}{$\mathrm{Cd}\left(\mathrm{mmol} \mathrm{L}^{-1}\right)$} & \multirow[t]{2}{*}{$\mathrm{S}\left(\mathrm{mmol} \mathrm{L} \mathrm{L}^{-1}\right)$} & \multicolumn{3}{|c|}{$\mathrm{Cd}$ concentration $\left(\mathrm{mg} \mathrm{kg}^{-1} \mathrm{DW}\right)$} & \multirow{2}{*}{$\frac{\text { S concentration }}{\left(\mathrm{g} \mathrm{kg}^{-1} \mathrm{DW}\right)}$} \\
\hline & & Apoplast & Symplast & Total & \\
\hline \multirow[t]{2}{*}{0.1} & 0.1 & $388.34 \pm 24.48 b$ & $266.26 \pm 00.17 \mathrm{~b}$ & $654.61 \pm 24.31 \mathrm{~b}$ & $1.50 \pm 0.19 \mathrm{~b}$ \\
\hline & 1.9 & $400.55 \pm 18.64 \mathrm{~b}$ & $250.89 \pm 09.07 \mathrm{~b}$ & $651.44 \pm 09.57 \mathrm{~b}$ & $2.91 \pm 0.10 \mathrm{a}$ \\
\hline \multirow[t]{2}{*}{0.5} & 0.1 & $814.58 \pm 20.00 \mathrm{a}$ & $503.58 \pm 24.11 \mathrm{a}$ & $1318.17 \pm 04.10 \mathrm{a}$ & $1.79 \pm 0.08 \mathrm{~b}$ \\
\hline & 1.9 & $903.81 \pm 13.75 \mathrm{a}$ & $505.73 \pm 31.33 \mathrm{a}$ & $1409.54 \pm 17.58 \mathrm{a}$ & $2.83 \pm 0.12 \mathrm{a}$ \\
\hline
\end{tabular}

Means \pm SEM followed by different letters in the column differ by Tukey's test $(p<0.05)$.

plants supplied with the $\mathrm{S}$ concentration of $0.1 \mathrm{mmol} \mathrm{L}^{-1}$ when plants were exposed to the $\mathrm{Cd}$ concentrations of 0.1 and $0.5 \mathrm{mmol} \mathrm{L}^{-1}$, respectively (Table 5).

\subsection{Pearson's correlation among the studied variables}

The highest correlation coefficients (r) are highlighted in Table 6. As can be observed in the table, the correlations between $\mathrm{V}_{\max }$ and $\mathrm{Cd}$ concentration in apoplast ( $\mathrm{r} \geq 0.97) ; \mathrm{V}_{\max }$ and $\mathrm{Cd}$ concentration in symplast $(r \geq 0.94) ; K_{m}$ and $C d$ concentration in apoplast $(r \geq 0.96)$; $\mathrm{K}_{\mathrm{m}}$ and $\mathrm{Cd}$ concentration in symplast $(\mathrm{r} \geq 0.98)$; $\mathrm{C}_{\mathrm{min}}$ and Cd concentration in apoplast ( $\mathrm{r} \geq 0.94) ; \mathrm{C}_{\min }$ and Cd concentration in symplast ( $r \geq 0.98$ ); $\alpha$ and Cd concentration in apoplast ( $r \geq 0.98)$; and $\alpha$ and $\mathrm{Cd}$ concentration in symplast $(r \geq 0.92)$ revealed that there is a close relationship between the $\mathrm{Cd}$ influx and the $\mathrm{Cd}$ accumulation site in the root system of the Massai grass. It is also noteworthy that the S concentration did not have a negative correlation $(p>0.05)$ with the variables of the study of Cd uptake kinetics by the Massai grass.

\subsection{Relationship between Cd influx and accumulation site}

The symplastic Cd influx was 41.5, 32.2, 37.6, and $32.7 \%$ when the Massai grass was exposed to the combinations of $\mathrm{Cd}\left(\mathrm{mmol} \mathrm{L}^{-1}\right)$ and $\mathrm{S}$ $(\mathrm{mmol} \mathrm{L}-1)$ concentrations of $0.1+0.1,0.1+1.9,0.5+0.1$, and $0.5+1.9$, respectively. Similarly, the accumulation of $\mathrm{Cd}$ in the root symplast was $40.7,38.5,38.8$, and $35.9 \%$ when plants were grown with the $\mathrm{Cd}\left(\mathrm{mmol} \mathrm{L}^{-1}\right)$ and $\mathrm{S}\left(\mathrm{mmol} \mathrm{L}^{-1}\right)$ combinations of $0.1+0.1$, $0.1+1.9,0.5+0.1$, and $0.5+1.9$, respectively (Fig. 3).

\section{Discussion}

The biomass production (shoots and roots) of the plants decreased with the higher exposure to $\mathrm{Cd}$ (Table 3), which was also reported in other studies (He et al., 2007; Stritsis and Claassen, 2013). This occurs because $\mathrm{Cd}$ changes the metabolism of nutrients, amino acids, and carbohydrates; degrades proteins and lipids; and damages the photosynthetic apparatus, among other factors (Benavides et al., 2005). 
Table 6

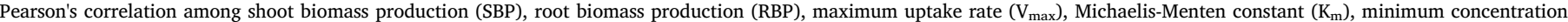

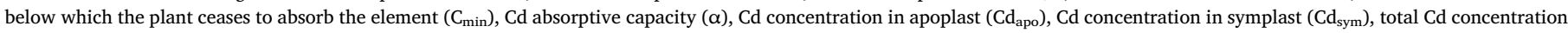
$\left(\mathrm{Cd}_{\text {tot }}\right)$, and $\mathrm{S}$ concentration $\left(\mathrm{S}_{\mathrm{con}}\right)$ of the Massai grass supplied with $\mathrm{S}$ and exposed to $\mathrm{Cd}(n=16)$. Bold numbers highlight correlations higher than 0.89 .

\begin{tabular}{|c|c|c|c|c|c|c|c|c|c|c|}
\hline & SBP & RBP & $\mathrm{V}_{\max }$ & $\mathrm{K}_{\mathrm{m}}$ & $\mathrm{C}_{\min }$ & $\alpha$ & $\mathrm{Cd}_{\mathrm{apo}}$ & $\mathrm{Cd}_{\text {sym }}$ & $\mathrm{Cd}_{\text {tot }}$ & $\mathrm{S}_{\text {con }}$ \\
\hline \multicolumn{11}{|l|}{ SBP } \\
\hline RBP & $0.96^{* *}$ & & & & & & & & & \\
\hline $\mathrm{V}_{\max }$ & $-0.76^{* *}$ & $-0.82^{* *}$ & & & & & & & & \\
\hline $\mathrm{K}_{\mathrm{m}}$ & $-0.75^{* *}$ & $-0.82^{* *}$ & $0.97^{* *}$ & & & & & & & \\
\hline $\mathrm{C}_{\min }$ & $-0.74 * *$ & $-0.81 * *$ & $0.94 * *$ & 0.98 ** & & & & & & \\
\hline$\alpha$ & $-0.78^{* *}$ & $-0.83^{* *}$ & $0.99 * *$ & $0.94 * *$ & $0.92^{* *}$ & & & & & \\
\hline $\mathrm{Cd}_{\text {apo }}$ & $-0.72^{* *}$ & $-0.78^{* *}$ & $0.97^{* *}$ & $0.96^{* *}$ & $0.94 * *$ & $0.98^{* *}$ & & & & \\
\hline $\mathrm{Cd}_{\mathrm{sym}}$ & $-0.72^{* *}$ & $-0.80^{* *}$ & $0.94 * *$ & $0.98^{* *}$ & $0.98^{* *}$ & $0.92^{* *}$ & $0.94 * *$ & & & \\
\hline $\mathrm{Cd}_{\text {tot }}$ & $-0.73^{* *}$ & $-0.79 * *$ & $0.97 * *$ & $0.98 * *$ & 0.97 ** & $0.97^{* *}$ & $0.99 * *$ & $0.97^{* *}$ & & \\
\hline $\mathrm{S}_{\text {con }}$ & $0.36^{\mathrm{ns}}$ & $0.29^{\mathrm{ns}}$ & $0.18^{\mathrm{ns}}$ & $0.10^{\mathrm{ns}}$ & $0.06^{\mathrm{ns}}$ & $0.15^{\mathrm{ns}}$ & $0.20^{\mathrm{ns}}$ & $0.09^{\mathrm{ns}}$ & $0.16^{\mathrm{ns}}$ & \\
\hline
\end{tabular}

${ }^{*} p<0.05 ;{ }^{* *} p<0.01{ }^{\mathrm{ns}}{ }^{- \text {not }}$ significant.

However, the biomass production of the root of the Massai grass supplied with the higher S concentration was $130 \%$ higher as compared with the biomass production of the grass cultivated with the lower $S$ concentration, when $0.1 \mathrm{mmol} \mathrm{L}^{-1} \mathrm{Cd}$ was provided in the nutrient solution, which is associated with the higher synthesis of amino acids, GSH, and PCs found under adequate S supply in other study with Massai grass (Rabêlo et al., unpublished data), since these metabolites are involved in Cd detoxification (Cobbett and Goldsbrough, 2002; Seth et al., 2012). Furthermore, the $S$ metabolism is involved in the synthesis of essential hormones for the adaptation of plants to adverse conditions, such as exposure to Cd (Capaldi et al., 2015). On the other hand, the higher S supply increased the damage caused by the larger concentration of Cd to the Massai grass (Table 3), in some sort of double toxicity (Cd and S). The toxicity caused by S may occur when the plant metabolism is altered (Ward, 1976) and, in this situation, the synthesis of GSH is also higher, but is aimed at signaling the lower need for S uptake (Herschbach and Rennenberg, 1994).

The changes in the root biomass production of the Massai grass resulted in depletion of Cd over time. This depletion in the solution of plants supplied with the higher S concentration (higher biomass production) was $26 \%$ higher as compared with the depletion in the solution of plants grown under the lower concentrations of $\mathrm{S}$ and $\mathrm{Cd}$ (lower biomass production) (Fig. 1A and B), while there was no effect of $\mathrm{S}$ on the depletion of $\mathrm{Cd}$ in the solution of plants exposed to the higher $\mathrm{Cd}$ concentration (biomass production unchanged) after $12 \mathrm{~h}$ of exposure (Fig. 1C and D). Cadmium uptake can occur either passive (LATS) or active (HATS) transport, and Cd can cross the plasma membrane through channels of divalent cations (e.g., $\mathrm{Ca}^{+2}$ and $\mathrm{Zn}^{+2}$ ) or by Cd-specific transporter proteins (Sloof et al., 1995; Chen et al., 2008). This uptake can be simulated by the Michaelis-Menten constant $\left(\mathrm{V}_{\max }\right.$ and $\mathrm{K}_{\mathrm{m}}$ ). The $\mathrm{V}_{\max }$ (defined as the product between the number of uptake sites per root unit by its working velocity; Epstein and Bloom, 2005) of the Massai grass exposed to the lower Cd concentration was not changed $\left(p>0.05\right.$ ) by the $S$ supply, unlike the $V_{\max }$ of the Massai grass exposed to the higher $\mathrm{Cd}$ concentration (Table 4). The higher $\mathrm{V}_{\max }$ observed in the Massai grass exposed to the higher $\mathrm{Cd}$ and $\mathrm{S}$ concentrations in relation to lower S concentration may be related to the alteration in the root architecture (Perriguey et al., 2008; Redjala et al., 2009), since the uptake area (more uptake sites) of the root system in these plants was larger than the elongation area (fewer uptake sites). Plants supplied with the higher S concentration possibly had a higher number of cortical cell layers compared to the plants cultivated with the

\section{Cd accumulation in apoplast and symplast (\%) \\ Influx apoplastic and symplastic of Cd (\%)}

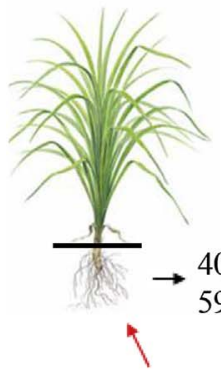

symplas $59.3 \%$ apoplast $41.5 \%$ symplastic $58.5 \%$ apoplastic

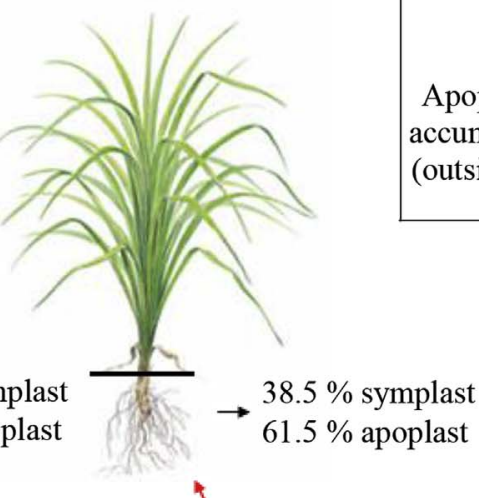

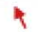

$32.2 \%$ symplastic $67.8 \%$ apoplastic

\begin{tabular}{|c|c|}
$58.5 \%$ apoplastic & $67.8 \%$ apoplastic \\
\hline S $0.1 \mathrm{mmol} \mathrm{L}^{-1}$ & $\mathrm{~S} 1.9 \mathrm{mmol} \mathrm{L}^{-1}$ \\
\multicolumn{2}{|c|}{$\mathrm{Cd} 0.1 \mathrm{mmol} \mathrm{L}^{-1}$}
\end{tabular}

Symplastic accumulation

(inside cell)

Apoplastic ccumulation (outside cell)

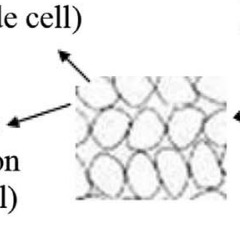

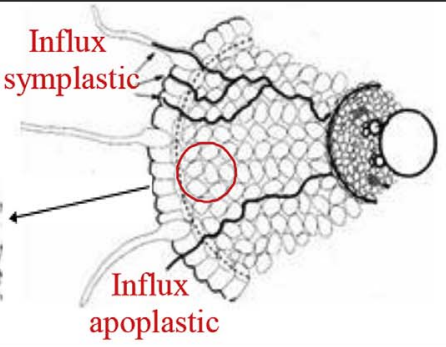

apoplastic

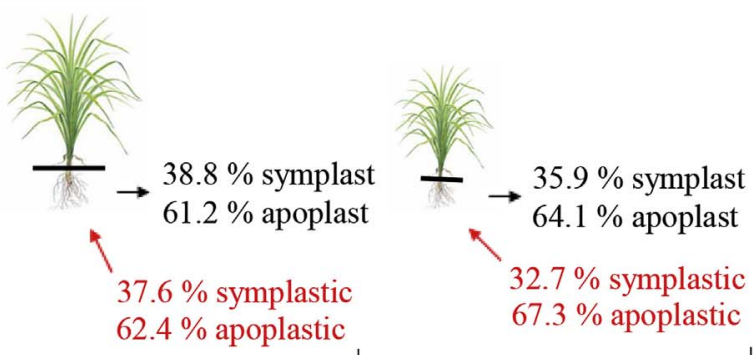

$\mathrm{S} 0.1 \mathrm{mmol} \mathrm{L} \mathrm{L}^{-1}$

$\mathrm{S} 1.9 \mathrm{mmol} \mathrm{L}^{-1}$

Cd $0.5 \mathrm{mmol} \mathrm{L}^{-1}$

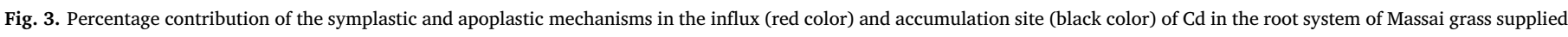

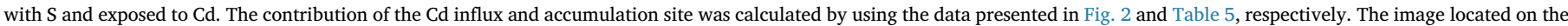

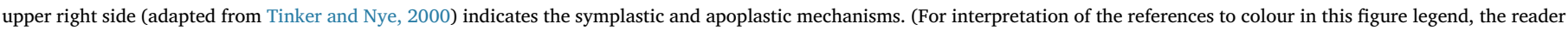
is referred to the web version of this article.) 
lower S concentration, which could lead to a difference in the ratio between the exposed plasmalemma area and the root biomass, which in turn would produce a difference in uptake rate $\left(\mathrm{V}_{\max }\right)$ (Zelko et al., 2008; Redjala et al., 2009). Bouranis et al. (2006) related that S-deprivation resulted in shorter lateral roots in the upper sectors and in a limited extension of the lignified layers towards the next lateral root carrying sector in maize plants.

Although the $\mathrm{V}_{\max }$ of the Massai grass exposed to the higher Cd concentration was changed by the S concentrations $(p<0.05), \mathrm{K}_{\mathrm{m}}$ remained constant (Table 4), indicating that the affinity of Cd by the uptake sites of the root system of the grass is not modified by S supply, just as Cd does not change the affinity of $S$ by the root uptake sites (Nocito et al., 2002). In addition, the $\mathrm{K}_{\mathrm{m}}$ of the Massai grass exposed to the $\mathrm{Cd}$ concentration of $0.1 \mathrm{mmol} \mathrm{L}^{-1}$ was 84 and $83 \%$ lower in relation to the $\mathrm{K}_{\mathrm{m}}$ of the plants exposed to the higher Cd concentration when $\mathrm{S}$ was supplied at 0.1 and $1.9 \mathrm{mmol} \mathrm{L}^{-1}$, but the amount of $\mathrm{Cd}$ absorbed (concentration of Cd x biomass production) was 66 and 963\% higher for the same comparison. It is important to note that in studies carried out with relatively high concentrations of $\mathrm{Cd}\left(>90 \mu \mathrm{mol} \mathrm{L}^{-1}\right)$ physical uptake parameters (diffusion and irreversible binding) tend to be accentuated, whereas active transport (HATS and LATS) characteristics are minimized (Cataldo et al., 1983). This indicates that $\mathrm{K}_{\mathrm{m}}$ cannot be used as the main factor to explain the elevated Cd uptake by plants grown in contaminated environments (Redjala et al., 2009). In this regard, the Cd uptake (high concentrations) probably is more deeply affected by the architecture than by the absorptive capacity $\left(\mathrm{V}_{\max }\right.$ and $\mathrm{K}_{\mathrm{m}}$ ) of the plant root (Redjala et al., 2009, 2010). This assumption becomes even clearer as we observe the negative correlation between $\alpha$ $\left(\mathrm{V}_{\max } / \mathrm{K}_{\mathrm{m}}\right)$ and the biomass production of the root system (Table 6$)$ and the high $\mathrm{C}_{\min }$ values (Table 4). High $\mathrm{C}_{\min }$ values (concentration in which the influx is equal to the efflux) are indicative of serious damage to the plasma membrane that may lead to cell death (Marschner, 1995). The $\mathrm{V}_{\max }$ values verified in this study are relatively smaller and the values of $\mathrm{K}_{\mathrm{m}}$ relatively higher than those pointed out in other studies (Catalado et al., 1983; Hart et al., 1998, 2002). This result probably occurred by the use of complete nutritive solution (Table 1), since the increase of the concentration of other divalent cations may inhibit $\mathrm{Cd}^{2+}$ influx due to the reduction of plasma membrane electronegativity, noncompetitive inhibition of influx by a variety of cations, or direct competition for specific cation transporters such as observed between $\mathrm{Cd}^{2+}$ and $\mathrm{Zn}^{2+}$ (Costa and Morel, 1993; Kinraide, 2001; Hart et al., 2002; Harris and Taylor, 2004).

Distinguishing uptake into the symplast from apoplastic binding is a major problem in studies of root uptake of divalent cations, such as $\mathrm{Cd}$ (Harris and Taylor, 2004). At concentrations above $5 \mu \mathrm{mol} \mathrm{L}^{-1} \mathrm{Cd}$, the physical uptake (Cd irreversibly bound to the root cell wall) can seriously distort any kinetic interpretation of Cd uptake in plants, which can explains the similarities in the symplastic uptake (Fig. 2B) between the most damaged root tissues $(1.9 \mathrm{~S}+0.5 \mathrm{Cd})$ and less damaged (0.1 S + $0.5 \mathrm{Cd}$ ) (Cataldo et al., 1983). Influx of Cd across the plasma membrane of root cells has been shown to occur via a concentrationdependent process exhibiting saturable kinetics, that Cd uptake by roots is controlled by a transport protein in the plasmalemma (Lux et al., 2011). Several results indicate that Cd gets through the plasmalemma of root cells in an opportunistic way, via other divalent cation carriers or channels, such as those for $\mathrm{Zn}^{2+}, \mathrm{Cu}^{2+}, \mathrm{Fe}^{2+}$ or $\mathrm{Ca}^{2+}$, that show poor selectivity (Cataldo et al., 1983; Costa and Morel, 1993; Zhao et al., 2002; Han et al., 2006). A saturable symplastic influx (Fig. 2A and B) component supports the existence of membrane transportermediated uptake, that in low external concentrations can be regarded as HATS (Redjala et al., 2009). The Cd species transported through the symplasm are unknown, but could include $\mathrm{Cd}^{2+}$ (predominant specie in the nutrient solution used in this study; Table 2) or Cd-chelates (Lux et al., 2011). Plants grown under the lower S concentration showed higher symplastic influx of Cd as compared with those supplied with the higher $\mathrm{S}$ concentration, when $\mathrm{Cd}$ was supplied at $0.1 \mathrm{mmol} \mathrm{L}^{-1}$
(Fig. 2A). Plants well nourished in S usually present higher synthesis of PCs when exposed to Cd (Bashir et al., 2015). PCs act in the sequestration of free $\mathrm{Cd}^{2+}$ ions in the cytosol, transporting them to organelles less sensitive to damage caused by $\mathrm{Cd}$, such as vacuoles (Cobbett and Goldsbrough, 2002). Thus, the accumulation of $\mathrm{Cd}$ in the vacuole of plants well nourished in $S$ tends to be larger and in plants cultivated with low S supply the accumulation tends to be smaller, which facilitates the transport of the $\mathrm{Cd}$ to the xylem by the symplastic via. Moreover, plants grown with proper S supply display detoxification mechanisms, such as Cd efflux from the cytoplasm to the apoplast, which is more efficient in comparison with plants cultivated with low $\mathrm{S}$ supply, such that the symplastic influx of Cd is usually lower under such conditions (Nocito et al., 2002; Jasinski et al., 2003; Van Belleghem et al., 2007). This fact becomes clearer as we observe that the difference between Cd concentration in the root symplast and root apoplast of the Massai grass supplied with the lower S concentration was lower than that of plants provided with the higher $S$ concentration (Table 5). In this way, the proper S supply benefits the Cd accumulation in the root apoplast of the Massai grass, which is desirable, since the main accumulation site of $\mathrm{Cd}$ in tolerant plants is the root apoplast (Wójcik et al., 2005; Akhter et al., 2014). By contrast, the symplastic influx of Cd of plants exposed to the higher concentration of $\mathrm{Cd}$ was higher when there was a higher S supply (Fig. 2B). This result is possibly linked to the partial loss of selectivity of the plasma membrane (high $\mathrm{C}_{\min }$ values), which may occur under high toxicity conditions (toxicity by $\mathrm{Cd}$ and $\mathrm{S}$ ) and lead to greater symplastic uptake (Zhao et al., 2002). In all treatments the linear component verified in Fig. 2A and B probably reflects a second pathway for Cd into the symplast (LATS) as demonstrated by Redjala et al. (2009). The linear component of the Cd uptake system is likely related to that Cd uptake may be passive (Costa and Morel, 1994) through channels of other divalent cations like Ca which are permeable to Cd (Lombi et al., 2001; Zhao et al., 2002). This LATS for Cd uptake was shown in concentration-dependent kinetics on plant organelles (Lux et al., 2011). The similarity of the slope for all treatments (Fig. 2A and B) suggests that $S$ not change the Cd uptake by LATS. The transition concentration that determines the switch between HATS and LATS depends on the ion (Marschner, 1995). For Cd, it seems that this switch is much lower for the non-accumulator plants than for hyperaccumulator plants (Redjala et al., 2009). Massai grass probably is a Cd hyperaccumulator plant (Rabêlo et al., unpublished dates), but the transition concentration that determined the switch between HATS and LATS was lower $\left(\sim 1 \mu \mathrm{mol} \mathrm{L}{ }^{-1}\right)$ for Massai grass exposed to the $\mathrm{Cd}$ concentration of $0.1 \mathrm{mmol} \mathrm{L}^{-1}$ (Fig. 2A) than switch related by Redjala et al. (2009) for Noccaea caerulescens $\left(10 \mu \mathrm{mol} \mathrm{L} \mathrm{L}^{-1}\right)$ exposed to $50 \mu \mathrm{mol} \mathrm{L}{ }^{-1}$, suggesting that the Cd uptake by Massai grass occurs predominantly through the LATS and the apoplastic via in high Cd concentrations.

Because of the high concentrations of Cd to which the Massai grass was exposed, we chose to use the equation described by Lombi et al. (2001) to calculate the apoplastic influx, since there are indications that the linear component of this equation can represent the apoplastic influx of Cd (Lux et al., 2011). The adoption of this equation for this purpose is not usual, but employing inadequate protocols to remove the Cd from the root apoplast may cause a high efflux of Cd from the symplast, mainly in cases when the plasma structure is seriously damaged (high $\mathrm{C}_{\min }$ values; Table 4 ), which may compromise the reliability of results (Lombi et al., 2001; Harris and Taylor, 2004). In this sense, the apoplastic uptake function that could be useful for modeling the Cd transport is not available from the literature, since in most studies of Cd uptake kinetics, desorption processes were performed, which more or less eliminated the apoplastic uptake (Redjala et al., 2009). However, the contribution of apoplast to the Cd total root uptake is very important, mainly when the Cd concentration is high. If the apoplastic barriers (particularly Casparian bands and suberin deposits) can blocking the cation flow towards stele and xylem (Lux et al., 2011), the apoplastic influx will accumulate $\mathrm{Cd}$ in the root only, while the sole 
symplastic influx would contribute to the shoot content (Redjala et al., 2009). However, it is also possible for $\mathrm{Cd}^{2+}$ and Cd-chelates to reach the xylem solely via an extracellular, apoplasmic pathway in regions of the root lacking a Casparian band (Lux et al., 2004). In this situation, the apoplastic root influx should be considered as an important mechanism in understanding the phytoaccumulation of this metal (Redjala et al., 2009). The apoplastic influx of Cd by the root system of the Massai grass exposed to the Cd concentrations of 0.1 and $0.5 \mathrm{mmol} \mathrm{L}^{-1}$ was higher when the plants were grown with the higher supply of $S$ (Fig. 2C and D). The amount and composition of suberin are among the major factors that limit the apoplastic displacement of water and inorganic ions (Schreiber et al., 2005). In this sense, it is possible that the Massai grass supplied with the higher S concentration tested in this study shows lower deposition of suberin between the epidermis and the cortex (apoplastic via), since the synthesis of suberin can be regulated by ethylene, and plants well nourished with $S$ show lower ethylene synthesis when exposed to Cd (Barberon et al., 2016; Khan et al., 2016). In this context, the lower deposition of suberin (mainly in regions near the Caspary strips) in plants grown with lower S supply may facilitate the apoplastic transport of Cd to the shoots, but this fact can increase the damage caused by Cd (Redjala et al., 2009). Redjala et al. (2010) stated that the apoplastic uptake of Cd by corn plants ranged from 15 to $82 \%$ as a function of the increase in the Cd concentration, whereas the apoplastic uptake of $\mathrm{Cd}$ by the Massai grass exposed to the lower $\mathrm{Cd}$ concentration ranged from $58.5\left(0.1 \mathrm{mmol} \mathrm{L}^{-1}\right)$ to $67.8 \%$ $\left(1.9 \mathrm{mmol} \mathrm{L}^{-1}\right)$ as the $\mathrm{S}$ concentration was increased (Fig. 3).

The reduced slope of the linear component in intact roots of the plants supplied with the higher S concentration in relation to the lower S concentration (Fig. 2C and D) was therefore probably the result of reduced Cd binding to cell wall constituents (e.g., cellulose, hemicellulose, and proteins) due the lower deposition of suberin between the epidermis and the cortex (apoplastic via) (Hart et al., 1998). Costa and Morel (1993) verified that the exchangeable fraction represented about $5 \%$ of the total absorbed $\mathrm{Cd}$ in the roots of Lupinus albus due to the presence of anionic charges on the cell wall (carboxylic groups). The cell wall, the intercellular spaces and the outer surface of the plasmalema delimit the apparent free space (AFS), where the element can enter by mass flow, diffusion, ion exchange and Donnan equilibrium (Marschner, 1995). However, the elements can also leave the AFS, since this process is reversible. Thus, physical interactions (e.g., electrostatic forces) such as cation exchange capacity (CEC) of carboxylic groups may influence the apoplastic uptake of Cd (Redjala et al., 2009). Although CEC is not an essential step in the passage of ions across the plasma membrane to the cytoplasm, it has an indirect effect, which is the increase of the cations concentration in the apoplast (Marschner, 1995). There is a rapid Cd accumulation in the apoplasm which is freely accessible to the outer solution when the Cd concentration in the nutrient solution is high (Redjala et al., 2010). The relative contribution of the apoplastic via increased when the Massai grass was cultivated with the higher concentration of S (Fig. 3), what suggest that S changes the composition of the cell wall and, consequently, the CEC of the roots of the Massai grass exposed to $\mathrm{Cd}$. Retention of $\mathrm{Cd}$ in roots is a factor that contributing to low Cd accumulation in shoots (Harris and Taylor, 2004), but in other study (Rabêlo et al., unpublished dates) we verified that the Cd accumulation in shoots of Massai grass was very high what suggest that $\mathrm{Cd}^{2+}$ and Cd-chelates to reach the xylem via an extracellular, apoplasmic pathway in regions of the root lacking a Casparian band in this plant. In this sense, it is possible that the Cd uptake through PCs-Cd in the AFS has contributed to higher Cd apoplastic uptake in plants cultivated with the higher concentration of $\mathrm{S}$, since plants properly supplied with S present high synthesis of PCs when exposed to Cd (Bashir et al., 2015). Mendoza-Cózatl et al. (2008) described that the PCs are involved in the transport of Cd from roots to shoots in Brassica napus plants.

Based on the conditions presented here, we observed that irrespective of the toxicity caused by the higher supply of $S$ to the plants exposed to the higher concentration of $\mathrm{Cd}$, the contribution of the apoplastic pathway in the Cd uptake by the Massai grass is a little higher (Fig. 3) under higher concentrations of $S$ in the root tissue (Table 5) in relation to the lower concentration, and that part of the Cd absorbed via apoplast by these plants is accumulated in symplast (Fig. 3), which suggests that the Cd not binding to the cell wall of the apoplast may enters the cells through transporters of the ZIP family located in the root apoplast (Guerinot, 2000; Lux et al., 2011). After the entering the cells, the $\mathrm{Cd}$ is complexed to S-containing molecules, such as Cd-PCs, Cd-PCs-sulfide and/or Cd-sulfide (Van Belleghem et al., 2007). Thus, analyzing the values in absolute terms (Cd concentration $x$ mass production), we note that the greater $S$ supply to the plants exposed to the Cd concentration of $0.1 \mathrm{mmol} \mathrm{L}^{-1}$ increased the amount of Cd absorbed by $129 \%$ in relation to the plants grown under lower $\mathrm{S}$ supply, indicating that regardless of the predominant mechanism in the Cd uptake (symplastic or apoplastic), the S supply is essential for the phytoextraction process, possibly due to the greater synthesis of PCs (Rabêlo et al., 2017a). To exemplify, Larsson et al. (2002) described that the Cd uptake by wild Arabdopsis thaliana plants was approximately $40 \%$ higher in relation to the uptake by plants containing the mutant cad1-3 (lower activity of the PC synthase enzyme, which controls the synthesis of PCs).

\section{Conclusions}

The exposure of Massai grass to high concentrations of Cd for longer periods indicated that this forage grass does not feature efficient detoxification mechanisms to be used in phytoextraction processes in environments with $\mathrm{Cd}$ concentrations greater than $0.1 \mathrm{mmol} \mathrm{L}^{-1}$. However, the Massai grass grown under adequate supply of $S$ showed tolerance to $\mathrm{Cd}\left(0.1 \mathrm{mmol} \mathrm{L}^{-1}\right)$, and thus we recommend sulfate fertilization for forage grasses used in the Cd extraction process.

Properly S supply decreased the contribution of symplastic and increased the contribution of apoplastic uptake of $\mathrm{Cd}$ by the Massai grass exposed to the lower concentration of $\mathrm{Cd}$. On the other hand, part of the Cd absorbed via apoplast was accumulated in symplast at the end of the growth of the Massai grass. Therefore, the influence exerted by the Cd transition (symplast-apoplast-symplast) upon the tolerance of plants cultivated under an adequate supply of $S$ should be better investigated.

\section{Contributions}

FHSR performed the experiment. LTJ contributed to the calculations while JL helped discuss the manuscript. All authors proofread the manuscript.

\section{Acknowledgments}

The authors acknowledge the following agencies for financial support: CAPES (Coordination for the Improvement of Higher Education Personnel; \#1332394) and FAPESP (São Paulo Research Foundation; \#2014/16731-7, \#2014/18735-0 and \#2015/21562-2).

\section{Appendix A. Supplementary data}

Supplementary data related to this article can be found at http://dx. doi.org/10.1016/j.plaphy.2017.10.018.

\section{References}

Akhter, M.F., Omelon, C.R., Gordon, R.A., Moser, D., Macfie, S.M., 2014. Localization and chemical speciation of cadmium in the roots of barley and lettuce. Environ. Exp. Bot. 100, 10-19. http://dx.doi.org/10.1016/j.envexpbot.2013.12.005.

Anjum, N.A., Hasanuzzaman, M., Hossain, M., Thangavel, P., Roychoudhury, A., Gill, S.S., Rodrigo, M.A.M., Adam, V., Fujita, M., Kizek, R., Duarte, A.C., Pereira, E., Ahmad, I., 2015. Jacks of metal/metalloid chelation trade in plants - an overview. Front. Plant Sci. http://dx.doi.org/10.3389/fpls.2015.00192. 
Barberon, M., Vermeer, J.E.M., De Bellis, D., Wang, P., Nasser, S., Andersen, T.G., Humbel, B.M., Nawrath, C., Takano, J., Salt, D.E., Geldner, N., 2016. Adaptation of root function by nutrient-induced plasticity of endodermal differentiation. Cell 164, 447-459. http://dx.doi.org/10.1016/j.cell.2015.12.021.

Bashir, H., Ibrahim, M.M., Bagheri, R., Ahmad, J., Arif, I.A., Baig, M.A., Qureshi, M.I., 2015. Influence of sulfur and cadmium on antioxidants, phytochelatins and growth in Indian mustard. AoB Plants. http://dx.doi.org/10.1093/aobpla/plv001.

Benavides, M.P., Gallego, S.M., Tomaro, M.L., 2005. Cadmium toxicity in plants. Braz J. Plant Physiol. 17, 21-34. http://dx.doi.org/10.1590/S1677-04202005000100003.

Bouranis, D.L., Chorianopoulou, S.N., Kollias, C., Maniou, P., Protonotarios, V.E., Siyiannis, V., Hawkesford, M.J., 2006. Dynamics of aerenchyma distribution in the cortex of sulfate-deprived adventitious roots of Maize. Ann. Bot. 97, 695-704. http:// dx.doi.org/10.1093/aob/mcl024.

Capaldi, F.R., Gratão, P.L., Reis, A.R., Lima, L.W., Azevedo, R.A., 2015. Sulfur metabolism and stress defense responses in plants. Trop. Plant Biol. 1, 1-14. http://dx.doi.org/10. 1007/s12042-015-9152-1.

Cataldo, D.A., Garland, T.R., Wildung, R.E., 1983. Cadmium uptake kinetics in intact soybean plants. Plant Physiol. 73, 844-848. http://dx.doi.org/10.1104/pp.73.3.844.

Chen, W., Li, L., Chang, A.C., Wu, L., Kwon, S., Bottoms, R., 2008. Modeling uptake kinetics of cadmium by field-grown lettuce. Environ. Poll. 152, 147-152.

Claassen, N., Barber, S.A., 1974. A method for characterizing the relation between nutrient concentration and flux into roots of intact plants. Plant Phisiol 54, 564-568. http://dx.doi.org/10.1104/pp.54.4.564.

Cobbett, C., Goldsbrough, P., 2002. Phytochelatins and metallothioneins: roles in heavy metal detoxification and homeostasis. Annu. Rev. Plant Biol. 53, 159-182. http://dx. doi.org/10.1146/annurev.arplant.53.100301.135154.

Costa, G., Morel, J.L., 1993. Cadmium uptake by Lupinus albus (L.): cadmium excretion, a possible mechanism of cadmium tolerance. J. Plant Nutr. 16, 1921-1929. http://dx. doi.org/10.1080/01904169309364661.

Costa, G., Morel, J.L., 1994. Efficiency of $\mathrm{H}^{+}$-ATPase activity on cadmium uptake by four cultivars of lettuce. J. Plant Nutr. 17, 627-637. http://dx.doi.org/10.1080/ 01904169409364754.

Epstein, E., Hagen, C.E., 1952. A kinetic study of the absorption of alkali cation by barley roots. Plant Phisiol 27, 457-474. http://dx.doi.org/10.1104/pp.27.3.457.

Epstein, E., Bloom, A.J., 2005. Mineral nutrition of Plants: Principles and Perspectives, second ed. Sinauer Associates, Sunderland.

Guerinot, M.L., 2000. The ZIP family of metal transporters. Biochim. Biophys. Acta 1465, 190-198. http://dx.doi.org/10.1016/S0005-2736(00)00138-3.

Gustafsson, J.P., 2012. Visual MINTEQ. Version 3.0. http://www2.lwr.kth.se/English/ OurSoftware/vminteq/Stockholm-Sweden.

Han, F., Shan, X., Zhang, S., Wen, B., Owens, G., 2006. Enhanced cadmium accumulation in maize roots - the impact of organic acids. Plant Soil 289, 355-368. http://dx.doi. org/10.1007/s11104-006-9145-9.

Harris, N.S., Taylor, G.J., 2004. Cadmium uptake and translocation in seedlings of near isogenic lines of durum wheat that differ in grain cadmium accumulation. BMC Plant Biol. http://dx.doi.org/10.1186/1471-2229-4-4.

Hart, J.J., Welch, R.M., Norvell, W.A., Sullivan, L.A., Kochian, L.V., 1998. Characterization of cadmium binding, uptake, and translocation in intact seedlings of bread and durum wheat cultivars. Plant Physiol. 116, 1413-1420. http://dx.doi.org/ 10.1104/pp.116.4.1413.

Hart, J.J., Welch, R.M., Norvell, W.A., Kochian, L.V., 2002. Transport interactions between cadmium and zinc in roots of bread and durum wheat seedlings. Physiol. Plant 116, 73-78. http://dx.doi.org/10.1034/j.1399-3054.2002.1160109.x.

He, J.Y., Zhu, C., Ren, Y.F., Jiang, D.A., Sun, Z.X., 2007. Root morphology and cadmium uptake kinetics of the cadmiumsensitive rice mutant. Biol. Plant 51, 791-794. http:// dx.doi.org/10.1007/s10535-007-0162-1.

Herschbach, C., Rennenberg, H., 1994. Influence of glutathione (GSH) on net uptake of sulphate and sulphate transport in tobacco plants. J. Exp. Bot. 45, 1069-1076. http:// dx.doi.org/10.1093/jxb/45.8.1069.

Jasinski, M., Ducos, E., Martinoia, E., Boutry, M., 2003. The ATP-binding cassette transporters: structure, function, gene family comparison between rice and Arabidopsis. Plant Physiol. 131, 1169-1177. http://dx.doi.org/10.1104/pp.102 014720.

Khan, M.N.A., Asgher, M., Per, T.S., Massod, A., Fatma, M., Khan, M.I.R., 2016. Ethylene potentiates sulfur-mediated reversal of cadmium inhibited photosynthetic responses in mustard. Front. Plant Sci. 7, 1628. http://dx.doi.org/10.3389/fpls.2016.01628.

Keleti, T., Welch, G.R., 1984. The evolution of enzyme kinetic power. Biochem. J. 223, 299-303. http://dx.doi.org/10.1042/bj2230299.

Kinraide, T.B., 2001. Ion fluxes considered in terms of membrane-surface electrical potentials. Aust. J. Plant Physiol. 28, 605-616. http://dx.doi.org/10.1071/PP01019.

Larsson, E.H., Asp, H., Bornman, J.F., 2002. Influence of prior $\mathrm{Cd}^{2+}$ exposure on the uptake of $\mathrm{Cd}^{2+}$ and other elements in the phytochelatin-deficient mutant, cad1-3, of Arabidopsis thaliana. J. Exp. Bot. 53, 447-453. http://dx.doi.org/10.1093/jexbot/53. 368.447.

Lavres Junior, J., Moraes, M.F., Cabral, C.P., Malavolta, E., 2008. Genotypic influence on the absorption and toxicity of manganese in soybean. Rev. Bras. Ciênc Solo 32, 173-181. http://dx.doi.org/10.1590/S0100-06832008000100017.

Lee, R.B., Rudge, R.A., 1986. Effects of nitrogen deficiency on the absorption of nitrate and ammonium by barley plants. Ann. Bot. 57, 471-486.

Lombi, E., Zhao, F.J., McGrath, S.P., Young, S.D., Sacchi, G.A., 2001. Physiological evi dence for a high-affinity cadmium transporter highly expressed in a Thlaspi caerulescens ecotype. New Phytol. 149, 53-60. http://dx.doi.org/10.1046/j.1469-8137. 2001.00003.x.

Lux, A., Šottníková, A., Opatrná, J., Greger, M., 2004. Differences in structure of adventitious roots in Salix clones with contrasting characteristics of cadmium accumulation and sensitivity. Physiol. Plant 120, 537-545. http://dx.doi.org/10.1111/j. 0031-9317.2004.0275.x.

Lux, A., Martinka, M., Vaculík, M., White, P.J., 2011. Root responses to cadmium in the rhizosphere: a review. J. Exp. Bot. 62, 21-37. http://dx.doi.org/10.1093/jxb/erq281. Malavolta, E., Vitti, G.C., Oliveira, S.A., 1997. Avaliação do estado nutricional das plantas: princípios e aplicações, second ed. (Piracicaba, Potafos).

Marschner, H., 1995. Mineral nutrition of Higher Plants. Academic Press, San Diego.

Mendoza-Cózatl, D.G., Butko, E., Springer, F., Torpey, J.W., Komives, E.A., Kehr, J.

Schroeder, J.I., 2008. Identification of high levels of phytochelatins, glutathione and cadmium in the phloem sap of Brassica napus. A role for thiol-peptides in the longdistance transport of cadmium and the effect of cadmium on iron translocation. Plant J. 54, 249-259. http://dx.doi.org/10.1111/j.1365-313X.2008.03410.x.

Mori, S., Kawasaki, A., Ishikawa, S., Arao, T., 2009. A new method for evaluating symplastic cadmium absorption in the root of Solanum melongena using enriched isotopes ${ }^{113} \mathrm{Cd}$ and ${ }^{114} \mathrm{Cd}$. Soil Sci. Plant Nutr. 55, 294-299. http://dx.doi.org/10.1111/j. 1747-0765.2009.00364.x.

Nocito, F.F., Pirovano, L., Cocucci, M., Sacchi, G.A., 2002. Cadmium-induced sulfate uptake in maize roots. Plant Physiol. 129, 1872-1879. http://dx.doi.org/10.1104/ pp.002659.

Perriguey, J., Sterckeman, T., Morel, J.L., 2008. Effect of rhizosphere and plant-related factors on the cadmium uptake by maize (Zea mays L.). Environ. Exp. Bot. 63, 333-341. http://dx.doi.org/10.1016/j.envexpbot.2007.12.014.

Rabêlo, F.H.S., Borgo, L., 2016. Changes caused by heavy metals in micronutrient content and antioxidant system of forage grasses used for phytoremediation: an overview. Cienc. Rural. 8, 1368-1375. http://dx.doi.org/10.1590/0103-8478cr20151291.

Rabêlo, F.H.S., Azevedo, R.A., Monteiro, F.A., 2017a. Proper sulfur supply reduces tiller mortality in the regrowth of Tanzania guinea grass used for cadmium phytoextraction. J. Soils Sediment. 17, 1427-1436. http://dx.doi.org/10.1007/s11368-0161429-y.

Rabêlo, F.H.S., Azevedo, R.A., Monteiro, F.A., 2017b. The proper supply of S increases amino acid synthesis and antioxidant enzyme activity in Tanzania guinea grass used for Cd phytoextraction. Water Air Soil Pollut. 228. http://dx.doi.org/10.1007/ s11270-017-3563-6.

Redjala, T., Sterckeman, T., Morel, J.L., 2009. Cadmium uptake by roots: contribution of apoplast and of high- and low-affinity membrane transport systems. Environ. Exp. Bot. 67, 235-242. http://dx.doi.org/10.1016/j.envexpbot.2009.05.012.

Redjala, T., Sterckeman, T., Morel, J.L., 2010. Determination of the different components of cadmium short-term uptake by roots. J. Plant Nutr. Soil Sci. 173, 935-945. http:// dx.doi.org/10.1002/jpln.201000003.

Ruiz, H.A., 1985. A graphico-mathematical method for the estimation of the kinetic parameters, $\mathrm{K}_{\mathrm{m}}$ and $\mathrm{V}_{\max }$. Rev. Ceres 32, 79-84.

Ruiz, H.A., Fernandes Filho, E.I., 1992. Cinética: software para estimar as constantes $\mathrm{V}_{\max }, \mathrm{K}_{\mathrm{m}}$ da equação de Michaelis-Menten. In: Proceedings of the 20th Reunião Brasileira de Fertilidade do solo e Nutrição de plantas. Campinas, Fundação Cargill, Piracicaba, pp. 124-125.

SAS Institute, 2008. SAS User's Guide: Statistics. Version 9.2. http://support.sas.com/ software/92/Cary-United States of America.

Schreiber, L., Franke, R., Hartmann, K.D., Ranathunge, K., Steudle, E., 2005. The chemical composition of suberin in apoplastic barriers affects radial hydraulic conductivity differently in the roots of rice (Oryza sativa L. cv. IR64) and corn (Zea mays L. cv. Helix). J. Exp. Bot. 56, 1427-1436. http://dx.doi.org/10.1093/jxb/eri144.

Seth, C.S., Remans, T., Keunen, E., Jozefczak, M., Gielen, H., Opdenakker, K., Weyens, N., Vangronsveld, J., Cuypers, A., 2012. Phytoextraction of toxic metals: a central role for glutathione. Plant Cell Environ. 35, 334-346. http://dx.doi.org/10.1111/j.13653040.2011.02338.x.

Sheoran, V., Sheoran, A.S., Poonia, P., 2016. Factors affecting phytoextraction: a review. Pedosphere 26, 148-166. http://dx.doi.org/10.1016/S1002-0160(15)60032-7.

Sloof, J.E., Viragh, A., van der Veer, B., 1995. Kinetics of cadmium uptake by green algae. Water Air Soil Poll. 83, 105-122. http://dx.doi.org/10.1007/BF00482598.

Sterckeman, T., Redjala, T., Morel, J.L., 2011. Influence of exposure solution composition and of plant cadmium content on root cadmium short-term uptake. Environ. Exp. Bot. 74, 131-139. http://dx.doi.org/10.1016/j.envexpbot.2011.05.010.

Stritsis, C., Claassen, N., 2013. Cadmium uptake kinetics and plants factors of shoot Cd concentration. Plant Soil 367, 591-603. http://dx.doi.org/10.1007/s11104-012 1498-7.

Systat Software Inc, 2015. Sigmaplot: Guide of Personal Computers. Version 13.0. http:// www.sigmaplot.co.uk/London-United Kingdon.

Tinker, P.B., Nye, P.H., 2000. Solute Movement in the Rhizosphere. Oxford University Press, New York.

Van Belleghem, F., Cuypers, A., Semane, B., Smeets, K., Vangronsveld, J., d'Haen, J., Valcke, R., 2007. Subcellular localization of cadmium in roots and leaves of Arabidopsis thaliana. New Phytol. 173, 495-508. http://dx.doi.org/10.1111/j.14698137.2006.01940.x.

Wang, J.J., 2003. Kinetics of manganese uptake by excised roots of sensitive and tolerant tobacco genotypes. J. Plant Nutr. 26, 1439-1450. http://dx.doi.org/10.1081/PLN 120021053.

Ward, G.M., 1976. Sulphur deficiency and toxicity symptoms in greenhouse tomatoes and cucumbers. Can. J. Plant Sci. 56, 133-137.

Wójcik, M., Vangronsveld, J., D'Haen, J., Tukiendorf, A., 2005. Cadmium tolerance in Thlaspi caerulescens. II. Localization of cadmium in Thlaspi caerulescens. Environ. Exp. Bot. 53, 163-171. http://dx.doi.org/10.1016/j.envexpbot.2004.03.011.

Xu, Y., Shi, D., Aristilde, L., Morel, F.M.M., 2012. The effect of pH on the uptake of zinc and cadmium in marine phytoplankton: possible role of weak complexes. Limnol. Oceanogr. 57, 293-304. http://dx.doi.org/10.4319/lo.2012.57.1.0000.

Zelko, I., Lux, A., Czibula, K., 2008. Difference in the root structure of hyperaccumulator Thlaspi caerulescens and non-hyperaccumulator Thlaspi arvense. Int. J. Environ. Pollut. 33, 123-132. http://dx.doi.org/10.1504/IJEP.2008.019387.

Zhao, F.J., Hamon, R.E., Lombi, E., McLaughlin, M.J., McGrath, S.P., 2002. Characteristics of cadmium uptake in two contrasting ecotypes of the hyperaccumulator Thlaspi caerulescens. J. Exp. Bot. 53, 535-543. http://dx.doi.org/10. 1093/jexbot/53.368.535. 